\title{
Variability of Southern Ocean Transports
}

\author{
BRADY S. FERSTER AND Bulusu SUbRAHMANYAM \\ School of the Earth, Ocean, and Environment, University of South Carolina, Columbia, South Carolina \\ ICHIRO FUKUMORI \\ Jet Propulsion Laboratory, California Institute of Technology, Pasadena, California
}

EBENEZER S. NYADJRO

Department of Physics, University of New Orleans, New Orleans, Louisiana

(Manuscript received 20 March 2018, in final form 17 September 2018)

\begin{abstract}
The Southern Ocean (SO) is capable of transporting vast amounts of salt, heat, and nutrients, which allows it to influence and regulate global climate. The variability of depth- and density-integrated volume transports in the SO is studied using the Estimating the Circulation and Climate of the Ocean (ECCO), version 4, release 3 (1992-2015), ocean state estimate. The estimate has a net eastward transport of $150.6 \pm 5.5,162.6 \pm 7.4$, and $148.2 \pm 5.4 \mathrm{~Sv}\left(1 \mathrm{~Sv} \equiv 10^{6} \mathrm{~m}^{3} \mathrm{~s}^{-1}\right)$ between the Atlantic-Indian, Indian-Pacific, and Pacific-Atlantic basins, respectively. The time-mean meridional volume transport across $30^{\circ} \mathrm{S}$ in the Atlantic is estimated to be $-1.4 \pm 0.6 \mathrm{~Sv},-14.4 \pm 3.5 \mathrm{~Sv}$ in the Indian basin, and $15.5 \pm 4.1 \mathrm{~Sv}$ in the Pacific, where negative values are southward. Trends in net volume transport between the basins are statistically insignificant. Within the water column, however, the middle and lower branches of the meridional overturning circulation have trends of -0.289 and $0.248 \mathrm{~Sv}$ decade ${ }^{-1}$ in the Atlantic basin. The Indian and Pacific basins have decreasing trends in their lower overturning cells. These results indicate increased overturning circulation within the lower branch in the South Atlantic and decreased lower branch circulation within the Indian and Pacific basins and have implications on the thermohaline-driven circulation. Using ECCO, we estimate a southward potential temperature transport of $-176.2^{\circ} \pm 197.2^{\circ} \mathrm{C} \mathrm{Sv}$ and salinity transport of $-1.71 \pm 22.4 \mathrm{psu}$ Sv into the SO and indicate potential temperature transport is increasing by $-15.0^{\circ} \pm 13.2^{\circ} \mathrm{C} \mathrm{Sv}$ decade $^{-1}$.
\end{abstract}

\section{Introduction}

The Southern Ocean (SO) is a major driving force in global climate and is an essential component in the globalscale meridional overturning circulation's (MOC) distribution of heat, mass, and freshwater. Strong westerly winds drive the Antarctic Circumpolar Current (ACC) across the three major ocean basins (Rintoul and Naveira Garabato 2013) and interact with eddies and jets to transfer energy and momentum from the ocean surface to the ocean floor (Moore et al. 2000; Thompson 2010; Mitsudera et al. 2018). These westerlies drive the strong zonal transports of the ACC but also result in the meridional Ekman-driven transport and upwelling along the sloping isopycnals. Ekman transport is important to global climate and budgets (i.e., heat and carbon) indirectly

Corresponding author: Brady S. Ferster, bferster@seoe.sc.edu via the contribution to sloping isopycnals (Toggweiler and Samuels 1995; Marshall and Speer 2012; Talley 2013; Rintoul and Naveira Garabato 2013). Together, the ACC, MOC, and polar gyres offer a three-dimensional passageway for global ocean circulation.

The MOC consists of two dominant counterrotating cells separated by a neutral-density surface of $27.6 \mathrm{~kg} \mathrm{~m}^{-3}$ (Marshall and Speer 2012). The upper cell of the MOC consists of northward-flowing Antarctic Intermediate and Subantarctic Mode Waters and southward-flowing Circumpolar Deep Waters (CDW). The bottom cell consists largely of the northward-flowing Antarctic Bottom Waters (AABW) and CDW returning southward. These MOC cells have been studied in recent model- and state estimate-based studies to better understand the mechanisms and forcings of interannual variations (Lumpkin and Speer 2007; Cabanes et al. 2008; Wunsch and Heimbach 2009; Talley 2013; Mazloff et al. 2013; Bishop et al. 2016). 
The global MOC is described in more detail within Marshall and Speer (2012) and Talley (2013).

The dominant mode of atmospheric variability in the Southern Hemisphere is the Antarctic Oscillation (AAO). Positive phases of the AAO induce a southward shift and increase in magnitude of the westerly winds. In recent decades, the AAO has been shown to display increasing tendencies of positive phases in model-based (Cai et al. 2003) and reanalysis (Thompson and Solomon 2002) studies and is thought to be driven through changes in the Antarctic ozone hole (Thompson et al. 2011). The shift in westerlies and increasing AAO tendencies are linked to the restructuring of the ACC fronts (Dong et al. 2006; Downes et al. 2011), driving the ACC southward (Hall and Visbeck 2002; Sen Gupta and England 2006). In the works of Sokolov and Rintoul (2009a,b), sea surface height is used to indicate a shift in the ACC southward by $0.6^{\circ}$ between 1992 and 2007. In the work of Farneti et al. (2015), using Co-ordinated Ocean-Ice Reference Experiment Phase II (CORE-II) simulations, zonal transports in the SO are positively correlated to the AAO between 1958 and 2007. Additional model (Meredith and Hogg 2006) and observational (Böning et al. 2008; Hogg et al. 2015) analyses discuss the influence and strength of the ACC as a result of the AAO. These analyses indicate the need to better account for eddy variability in both fine- and coarse-resolution ocean models, as only small trends are found in ACC transport over multiple decades in response to increased westerlies.

While the CORE-II simulations cover multiple decades (1948-2009), more recent state estimates covering shorter periods have used improved model physics and in situ data to model the state of the ocean (Mazloff et al. 2010; Forget et al. 2015, 2016; Fukumori et al. 2017; Verdy and Mazloff 2017). The recent state estimate of the Consortium for Estimating the Circulation and Climate of the Ocean, version 4, release 3 (ECCO V4r3, hereinafter ECCO; Fukumori et al. 2017), models the time period 1992-2015. ECCO is a general circulation model (GCM) product and could further indicate changes in SO transports and the state of the climate. Although other state estimates, such as the Southern Ocean State Estimate (SOSE) (Mazloff et al. 2010; Verdy and Mazloff 2017), include finer eddypermitting resolutions, ECCO has a longer temporal and a larger spatial (global) extent. ECCO has been shown to adequately resolve large-scale ocean circulation and is consistent with observations (Forget et al. 2015; Buckley et al. 2017a,b; Fukumori et al. 2017).

The objective of this paper is to analyze the magnitude and trends in subtropical MOC and the interbasin zonal transports using ECCO. To examine the state of the SO MOC, meridional transports and trends are analyzed within the different water masses, based on density.
The null hypothesis is that there are no significant trends in either the zonal or meridional depth- and densityintegrated volume transports throughout the 1992-2015 period. Potential temperature and salt transports are further analyzed within the SO, with the null hypothesis that there are no significant trends between 1992 and 2015. Previous works have shown regional temperature and salinity changes within the SO (Gille 2002, 2008; Durack and Wijffels 2010), in which the ECCO transports could be used to explain the changes in ocean state variables. The analyses described in this paper investigate the strength of the ACC and MOC over a $24-y r$ period, with important results with respect to ocean heat content, sea ice concentrations, and air-sea exchange studies.

\section{Data and methods}

\section{a. ECCO ocean state estimate}

The ocean state estimates of the ECCO Consortium provide a convenient means by which to study ocean circulations and its temporal variations. ECCO is directed at making the best possible estimates by combining stateof-the-art ocean circulation models with nearly complete global ocean datasets in a physically and statistically consistent manner (Wunsch and Heimbach 2009). ECCO's ocean description is more complete than that of observations alone, as no observing system measures the complete state of the ocean in terms of variables (e.g., threedimensional time-varying velocity) and spatiotemporal extent (viz., all corners of the ocean from the surface to the bottom throughout the analysis period). The ECCO estimate is closer to observations than model simulations that are unconstrained by such measurements. In addition, unlike many other data assimilation products, the ECCO estimate is physically consistent in both state and its temporal evolution owing to the nature of its model-data synthesis. For instance, property budgets can be closed in terms of explicit physical processes. Here, we take advantage of these characteristics to explore the SO using the latest estimate of the ECCO Consortium.

The Consortium's latest product V4r3 (Fukumori et al. 2017) spans the period from 1992 to 2015 and integrates nearly all extant ocean observations during this time with a coupled ocean-sea ice model based on the MIT general circulation model (MITgcm). The ECCO estimate has a nominal $1^{\circ}$ horizontal grid spacing with 50 vertical layers ranging in thickness from $10 \mathrm{~m}$ near the surface to $456 \mathrm{~m}$ near the bottom at $6134-\mathrm{m}$ depth. The model uses a so-called latitude-longitude cap (LLC) grid that consists of a latitude-longitude grid except for the Arctic domain, where instead a separate Cartesian coordinate system ("cap") is used to avoid the singularity of 
the former [see Forget et al. (2015) for details]. The ECCO product also employs three-dimensional, timeinvariant mixing coefficients, further detailed in Forget et al. (2015).

In situ measurements are relatively limited in the high latitudes of the SO even though significantly improved under the Argo program (Lyman and Johnson 2014). The sparseness of the observations is mitigated by ECCO's dynamical system, which carries data information spatially and temporally across the modeled domain. ECCO has an average spatial resolution of $62 \mathrm{~km}$ south of $30^{\circ} \mathrm{S}$ (Forget et al. 2015), is atmospherically forced by ERA-Interim (Dee et al. 2011), and employs an updated sea ice model (Losch et al. 2010). ECCO additionally uses satellite-derived sea surface salinity and ocean bottom pressure observations. This release of ECCO represents the first multidecadal ocean state estimate that is truly global, including the Arctic. Basic descriptions of the estimate's property distribution can be found in reports by Buckley et al. (2017a,b) and Forget et al. (2015).

\section{b. Estimation of depth-integrated volume, salinity, and potential temperature transports}

Depth-integrated volume transports are calculated using ECCO within the region south of $30^{\circ} \mathrm{S}$. The AtlanticIndian exchange is defined at $20^{\circ} \mathrm{E}$, the Indian-Pacific at $145^{\circ} \mathrm{E}$, and the Pacific-Atlantic at $70^{\circ} \mathrm{W}$. The meridional boundary of transports is defined at $30^{\circ} \mathrm{S}$. For these analyses, the ACC region is defined as $45^{\circ}-60^{\circ} \mathrm{S}$, the midlatitude area is $30^{\circ}-45^{\circ} \mathrm{S}$, and the high latitudes are poleward of $60^{\circ} \mathrm{S}$.

Using equations previously established (Ganachaud et al. 2000; Stammer et al. 2003; Talley 2008; Nyadjro et al. 2011), meridional volume transport $F_{v}$ in Sverdrups $\left(1 \mathrm{~Sv} \equiv 10^{6} \mathrm{~m}^{3} \mathrm{~s}^{-1}\right)$ is represented as

$$
F_{v}=\int_{-H}^{z_{o}} \int_{0}^{L} v(x, z) d x d z
$$

where $x$ and $z$ are the zonal and vertical coordinates, respectively, $H$ is the water column thickness from the sea surface to ocean bottom (maximum depth of $6134 \mathrm{~m}$ ), $z_{o}$ is the ocean surface, and $L$ is the zonal expanse $(\mathrm{m})$ of the ocean section. The $v(u)$ is the meridional (zonal) oceanic velocity $\left(\mathrm{m} \mathrm{s}^{-1}\right)$ and is perpendicular to the zonal (meridional) transect. A positive meridional component thus represents a northward velocity. For zonal volume transports, the meridional velocity $v$ in Eq. (1) is replaced with $u$ (the zonal velocity) and the corresponding integral $d y$. The zonal component is positive for eastward velocity. In the estimation of transports, the residual velocity $v(u)$ is the sum of the ECCO-output-resolved and bolus velocities, where the bolus component accounts for unresolved eddies. To account for bathymetry, ECCO provides a relative grid thickness factor, which is applied when necessary to account for cells that do not occupy the full nominal thickness.

Both salinity and potential temperature fluxes are integrated to calculate transports from the surface to the ocean bottom (maximum depth of $6134 \mathrm{~m}$ ) over the model's 50 depth layers, accounting for the varying layer thicknesses. In its entirety, volume, salinity, and heat budgets can be evaluated for conservation using the methods depicted in Piecuch (2017). In this analysis, we are using advective and diffusive transports to analyze changes in depth-integrated horizontal net transports. The net salinity and potential temperature transports are the sum of advective and diffusive fluxes that are available individually as ECCO output.

\section{c. Estimation of neutral density}

Neutral density $\gamma^{n}$ is not an ECCO output but was calculated according to the methods of Jackett and McDougall (1997). The advantage over potential density or a density anomaly is that neutral density allows for increased accuracy of analysis of isopycnals within the deep ocean. This method is a better characterization of the water masses in the region, such as the CDW, North Atlantic Deep Waters (NADW), and AABW. Neutral density is estimated for each $(x, y, z)$ grid along depth layers as a function of time and is used to differentiate the upper and lower cells of the MOC. Monthly residual transports are binned based on the range $\gamma^{n} \leq$ 27.72, 27.72 $<\gamma^{n} \leq 28.11$, and 28.11 $<\gamma^{n}$ (Ganachaud and Wunsch 2000) that define the three branches of the MOC. These neutral-density surfaces represent the Antarctic Intermediate and Subantarctic Mode Waters, $\mathrm{CDW}$, and the AABW for the upper and lower cells of the meridional circulation (Ganachaud and Wunsch 2000). Comparing transport in density space, rather than in depth, better represents the mean- and eddy-driven components of the MOC and differentiates whether there are significant changes in circulation.

\section{d. Anomalies and regression}

To estimate anomalies, monthly mean climatology from ECCO (1992-2015) is removed from the monthly record, effectively removing seasonality. The 288 monthly anomalies are used in a least squares linear regression fit (Watson 1967; Dytham 2011) to estimate the trends in horizontal transports from 1992 through 2015. To test the hypothesis of no change in transport, an alpha of 0.05 is used to indicate if the regression is significant at the $95 \%$ confidence level. Any $p$ value larger than the alpha level indicates that a trend is not significantly 

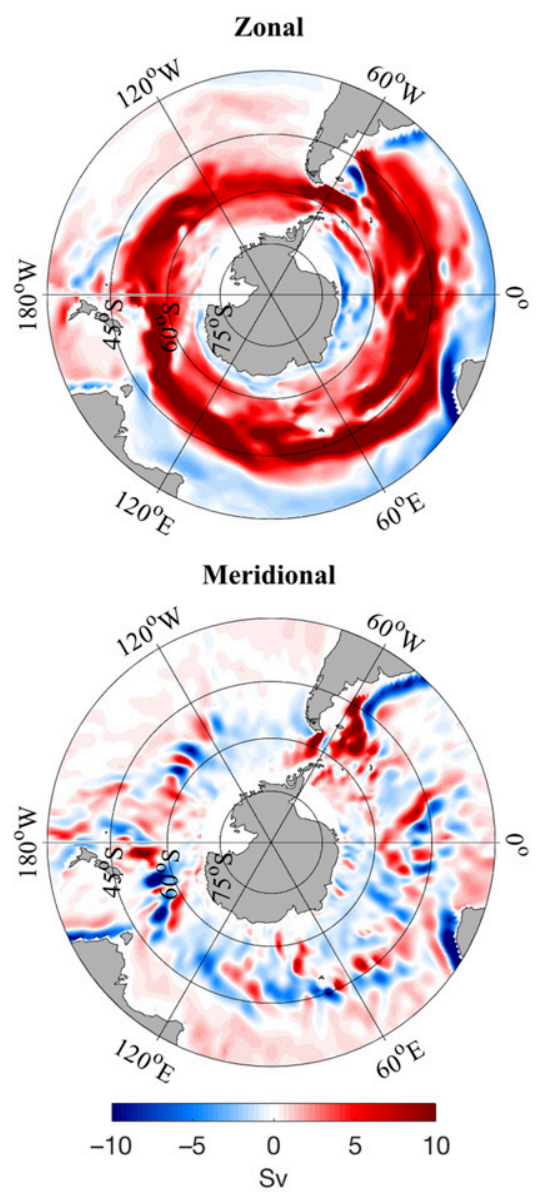

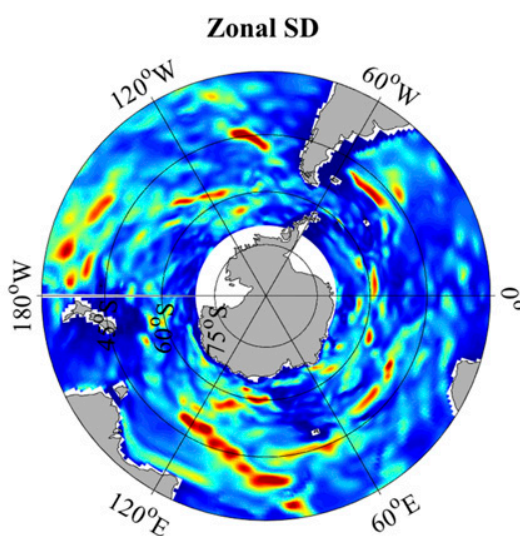

Meridional SD

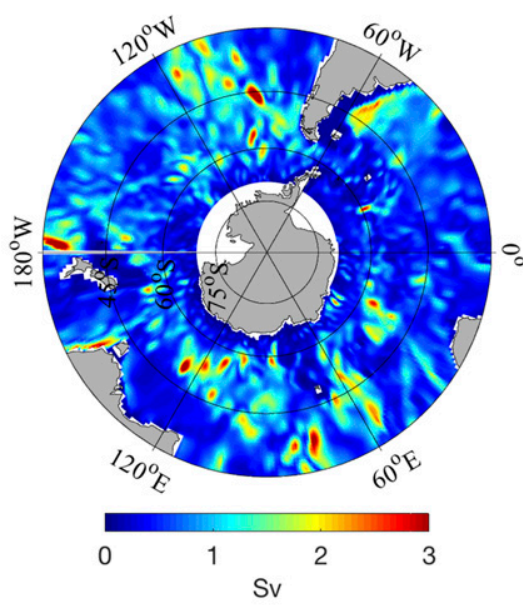

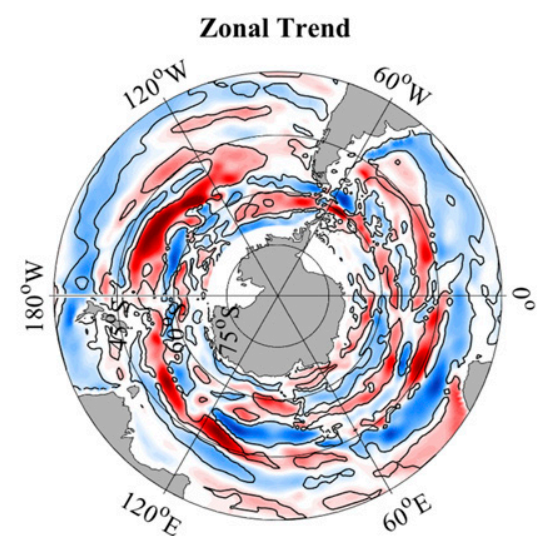

Meridional Trend

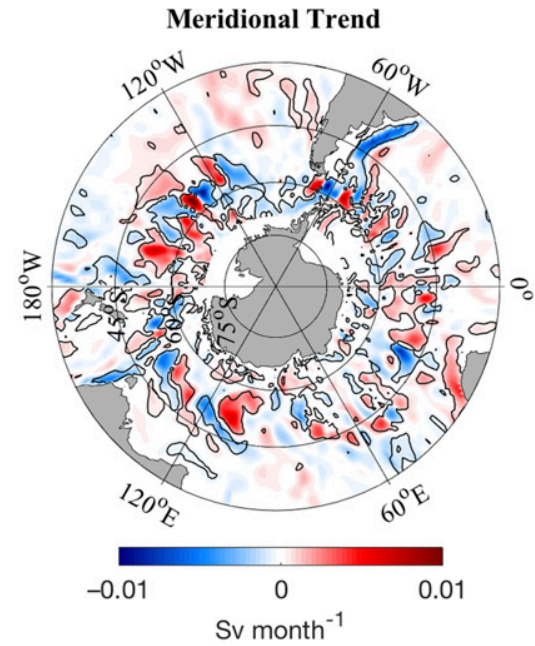

FIG. 1. ECCO V4r3 (1992-2015) (left) time-mean (Sv), (center) standard deviation (SD; Sv), and (right) coefficients of regression (Sv month ${ }^{-1}$ ) of (top) zonal and (bottom) meridional depth-integrated volume transports for the SO. Zonal (meridional) transports in red depict an eastward (northward) direction. The coefficients of regression in the right panels are computed spatially with zonal and meridional depthintegrated transport in units of Sverdrups per month. The linear regressions significant under an alpha of 0.05 are contoured in black.

different from zero and thus does not provide evidence to support that a trend exists. The Lilliefors test (Lilliefors 1967) and Cook's distance (Cook 1977) are used to test each horizontal transport for normality and influential data points (leverage), respectively. To test for autocorrelation, Durbin-Watson values are calculated (Durbin and Watson 1950). The critical values for the Durbin-Watson statistic are 1 and 3, in which most transports show signs of slight positive autocorrelation (between 1 and 2). To account for the slight positive autocorrelation and few monthly anomalies with large leverage, an additional regression is computed using a nonparametric approach, Sen's slope (Sen 1968), which is insensitive to outliers and derived using the median. In each instance, both parametric and nonparametric methods produce similar slopes and significance, despite slight autocorrelation and anomalies of large residuals. We discuss our results in terms of the least squares linear regression statistics but have included the nonparametric values in the tables due to the potential influence of outliers. The slopes of the least squares linear regression are additionally referred to in units per decade $\left(\right.$ decade $\left.^{-1}\right)$. For the regressions that are shown to be significantly different from zero, confidence intervals for the slopes are plus or minus the standard error multiplied by the critical $t$ value (1.96).

\section{Results and discussion}

\section{a. Depth-integrated volume transports}

ECCO resolves a significant amount of the ocean's variability (shown in Fig. 1), even for eddy-dominated regions like the SO (Forget et al. 2015, 2016; Fukumori et al. 2017; Buckley et al. 2017b). Depth-integrated residual volume transports from the surface to ocean 


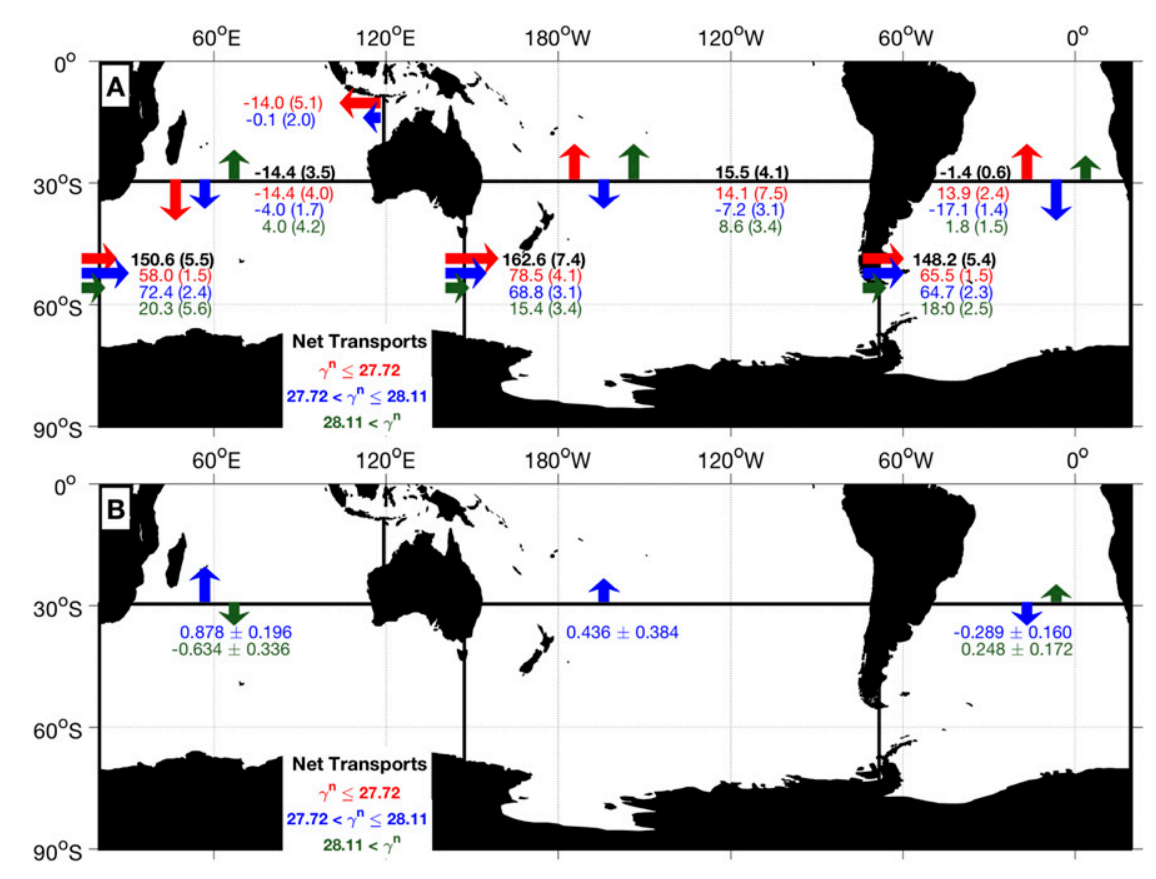

FIG. 2. (a) ECCO's 24-yr time-mean depth-integrated residual volume transports (Sv) and monthly standard deviations (in parentheses) across each of the basins. (b) The slopes and 95\% confidence intervals $\left(\mathrm{Sv}_{\text {decade }}{ }^{-1}\right)$ for the least squares linear regression of the 288 monthly anomalies that are statistically significant. $\operatorname{Red}\left(\gamma^{n} \leq 27.72 \mathrm{~kg} \mathrm{~m}^{-3}\right)$ represents the surface and mode waters, blue $\left(27.72 \mathrm{~kg} \mathrm{~m}^{-3}<\gamma^{n} \leq 28.11 \mathrm{~kg} \mathrm{~m}^{-3}\right)$ the $\mathrm{CDW}$, and green $\left(\gamma^{n}>\right.$ $28.11 \mathrm{~kg} \mathrm{~m}^{-3}$ ) the AABW. The Atlantic-Indian Ocean border is defined as $20^{\circ} \mathrm{E}$, the IndianPacific border at $145^{\circ} \mathrm{E}$, and the Pacific-Atlantic border at $70^{\circ} \mathrm{W}$. The meridional transport is estimated across $30^{\circ} \mathrm{S}$. The estimate for the meridional transport through the Bering Strait is 0.9 $\pm 0.5 \mathrm{~Sv}$ from the Pacific to the Atlantic Ocean.

bottom are explored and compared to previous model and in situ studies. As we are not balancing budgets [discussed in detail by Piecuch (2017)], only the horizontal transports are analyzed. Within all three basins, the midlatitude $\left(30^{\circ}-45^{\circ} \mathrm{S}\right)$ trends oppose the zonal transports (Fig. 1). The trends indicate that westward transport is decreasing in the Indian basin and that eastward transport is decreasing in the Pacific and Atlantic basins at the midlatitudes.

Zonal transports within the ACC $\left(45^{\circ}-60^{\circ} \mathrm{S}\right)$ and SO (south of $30^{\circ} \mathrm{S}$ ) are influenced by shifts in the subtropical and polar gyres (Wang et al. 2011). Net eastward zonal transports are significantly decreasing in the central South Atlantic midlatitude gyre $\left(30^{\circ}-45^{\circ} \mathrm{S}\right)$. This is likely influenced by the acceleration and southward shift of the Subtropical Atlantic Gyre (Vianna and Menezes 2011). Similarly, the South Pacific Gyre is intensifying and shifting southward (Roemmich et al. 2007, 2016). In the Indian basin, ECCO also indicates both meridional boundary currents and zonal basin transports decreasing over time. The opposing trends in the midlatitude gyre of the Indian basin illustrate deceased horizontal transports that could be a result from a weakening subtropical
Indian Ocean Gyre, which has previously been shown to decrease seasonally (Ffield et al. 1997). ECCO, however, shows there are no meridional depth-integrated transport trends in the midlatitudes and large high-latitude variability and trends.

Opposing trends in the north-south extent of the ACC demonstrate narrowing of zonal transports, corroborated in model-based analyses owing to the poleward shift in subtropical gyres (Wang et al. 2011) and shift in the AAO (Farneti et al. 2015). Both zonal and meridional changes along the Agulhas Current denote an opposing trend to the transports, which has been previously described as broadening in the Agulhas (Beal and Elipot 2016). The meridional depthintegrated transport trends depict changes along the ACC and boundary currents, with significant intensifying Malvinas, Benguela, and East Australian Currents.

Figure 2 depicts the 24-yr time-mean depth- and density-integrated transports and standard deviations across each of the basin boundaries based on monthly means. Within Fig. 2, positive values depict eastward (zonal) or northward (meridional) transports, while 


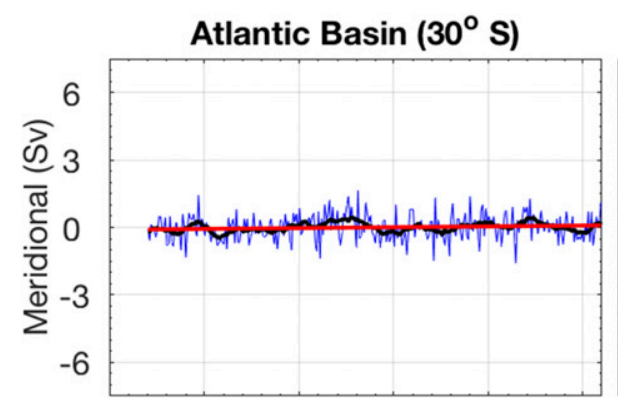

Pacific-Atlantic Exchange

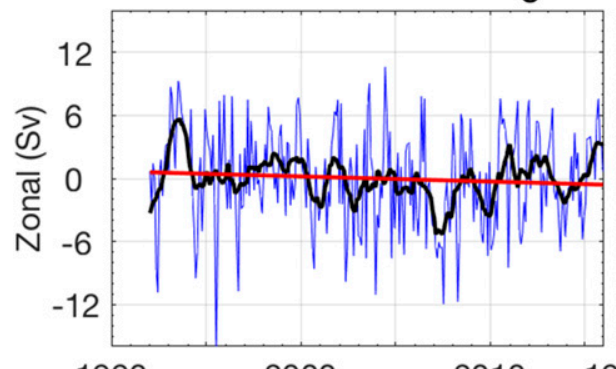

1990

2000

2010

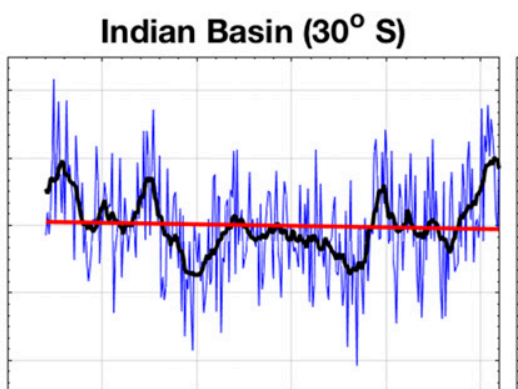

Atlantic-Indian Exchange

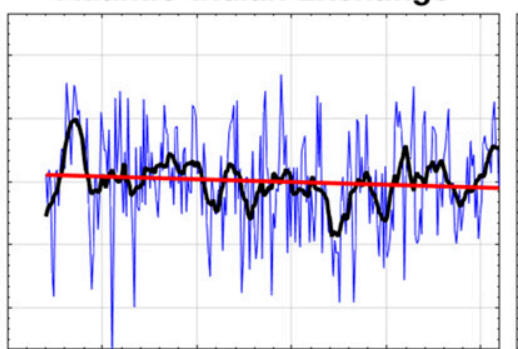

1990

2000

2010

1990

Pacific Basin $\left(30^{\circ} \mathrm{S}\right)$

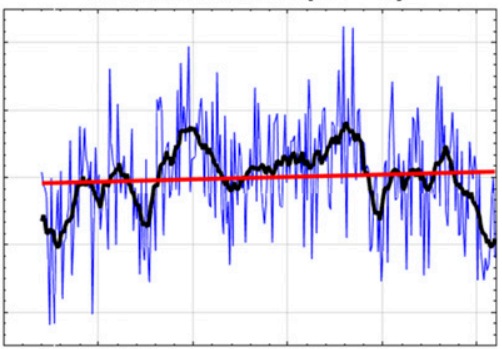

Indian-Pacific Exchange

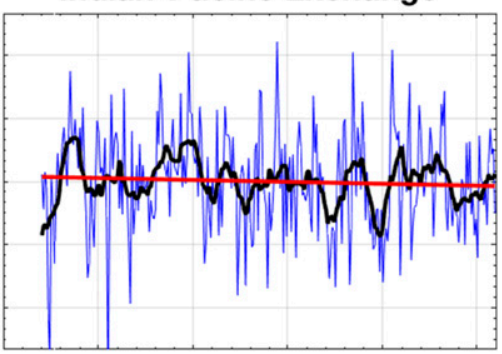

2000

2010

FIG. 3. Monthly climatological anomalies of depth-integrated transports (blue), 12-month running mean (black), and least squares regression line (red). The associated statistics are found in Table 1. The Atlantic-Indian Ocean border is defined as $20^{\circ} \mathrm{E}$, the Indian-Pacific border at $145^{\circ} \mathrm{E}$, and the Pacific-Atlantic border at $70^{\circ} \mathrm{W}$. The meridional transport is estimated across $30^{\circ} \mathrm{S}$.

negative values indicate westward or southward transports, respectively. ECCO has very similar time-mean transports and variability to other model-based (Stammer et al. 2003; Mazloff et al. 2010) and observational state estimate studies (MacDonald and Wunsch 1996; Ganachaud and Wunsch 2000). Each of the basin transports are directly estimated across the $30^{\circ} \mathrm{S}$ latitude border and summed along the respective basins' longitude, and net meridional transports from the basins are approximately zero.

In estimating with ECCO, the results are discussed in terms of the horizontal depth-integrated volume transport time-mean and standard deviation from 1992 through 2015. We estimate that the meridional transport through the Bering Strait is $0.9 \pm 0.5 \mathrm{~Sv}$, and the zonal transport of the Indonesian Throughflow region is $-14.0 \pm 5.0 \mathrm{~Sv}$. Within ECCO (Fig. 2), the Atlantic time-mean meridional transport is estimated to be approximately $-1.4 \pm 0.6 \mathrm{~Sv}$ southward. The Indian Ocean provides the SO basins with a net southward transport of $-14.4 \pm 3.5 \mathrm{~Sv}$, while the Pacific basin has a net northward transport of $15.5 \pm 4.1 \mathrm{~Sv}$. The ECCO product has a time-mean net meridional southward transport of $-0.30 \pm 0.56 \mathrm{~Sv}$ at $30^{\circ} \mathrm{S}$. Although the entire hydrological cycle is not analyzed (i.e., precipitation, evaporation, and runoff), these meridional transport estimates are similar to Ganachaud and Wunsch (2000) and Stammer et al. (2003). Ganachaud and Wunsch (2000) estimated time-mean meridional transport of $-1 \mathrm{~Sv}$ in the Atlantic, $-16 \mathrm{~Sv}$ in the Indian, and $17 \mathrm{~Sv}$ in the Pacific basins. Stammer et al. (2003) estimated transports of $0 \pm 1.9 \mathrm{~Sv}$ in the Atlantic, $-11.5 \pm 5 \mathrm{~Sv}$ in the Indian, and $11.5 \pm 4 \mathrm{~Sv}$ in the Pacific basins. The variability within ECCO basin transports is indicated within Figs. 2 and 3.

Zonal volume transports estimated from ECCO are similar to those of MacDonald and Wunsch (1996), Ganachaud and Wunsch (2000), and Mazloff et al. (2010) in magnitude and variability within the entirety of the region of study. The ECCO time-mean and standard deviation of residual transport within the Drake Passage is calculated to be $148.2 \pm 5.4 \mathrm{~Sv}$ from 1992 to 2015 . The ECCO time-mean estimate of Drake Passage transports are similar to previous estimates: $153 \pm 5 \mathrm{~Sv}$ of Mazloff et al. (2010), $142 \pm 5 \mathrm{~Sv}$ (MacDonald and Wunsch 1996), and $140 \pm 6 \mathrm{~Sv}$ (Ganachaud and Wunsch 2000), but are based on different time periods and depth of integration. ECCO estimated larger transports than an observational study approximation of $134 \pm 11 \mathrm{~Sv}$ (Cunningham et al. 2003) and model study estimates of $134.9 \pm 1 \mathrm{~Sv}$ (Sloyan and Rintoul 2001) and $124 \pm 5$ Sv (Stammer et al. 2003). ECCO differs from previous Drake Passage estimates based on the depth of integration, resolution, and the temporal period analyzed. With strong model similarities between ECCO and Mazloff et al. (2010), ECCO estimates the mean Drake Passage transport to 
be $147.8 \pm 5.3 \mathrm{~Sv}$ over the latter's time period (2005-10). The Mazloff et al. (2010) estimate is greater than that of the ECCO time-mean estimate but is within one standard deviation. Buckley et al. (2017b) found the climatological estimate of mean Drake Passage transport to be $146 \mathrm{~Sv}$ (years 1994-2013), where in this analysis ECCO estimated $146.6 \pm 5.7 \mathrm{~Sv}$ between 1994 and 2013.

The Drake Passage estimates by ECCO are far below the more recent observational study of $173.3 \pm 10.7 \mathrm{~Sv}$ (Donohue et al. 2016), suggesting bias in model physics, spatial-temporal differences, or errors associated with observations. Donohue et al. (2016) determined the 2007-11 mean barotropic transport to be $45.6 \mathrm{~Sv}$ and baroclinic transport of $127.7 \mathrm{~Sv}$, totaling $173.3 \mathrm{~Sv}$, which is greater than the maximum ECCO-derived transport. The ECCO 2007-11 mean Drake Passage transport is $146.8 \pm 5.5 \mathrm{~Sv}$, outside of three standard deviations from the Donohue et al. (2016) approximation. The Indian-Pacific passage (referred by the SR3 sampling line) additionally estimated transports similar to previous studies (Ganachaud and Wunsch 2000; Mazloff et al. 2010). The ECCO-estimated SR3 line transport of $162.6 \pm 7.4 \mathrm{~Sv}$ is between Ganachaud and Wunsch's (2000) estimate of $157 \pm 10 \mathrm{~Sv}$ and Mazloff et al.'s (2010) estimate of $164 \pm 6 \mathrm{~Sv}$. Over the same time period (2005-10) as Mazloff et al. (2010), ECCO estimates $161.9 \pm 8.1 \mathrm{~Sv}$ for the SR3 line. ECCO estimates the time-mean Atlantic-Indian basin exchange to be $150.6 \pm 5.5 \mathrm{~Sv}$. To compare with the model study by Stammer et al. (2003), ECCO estimates the 1993 to 2000 Atlantic-Indian exchange to be $151.7 \pm 5.1$, greater than their $124 \pm 6 \mathrm{~Sv}$ approximation.

To analyze the trends of the SO horizontal depthintegrated residual volume transports (Fig. 3), monthly climatology is removed at each time step from the transect lines depicted in Fig. 2. These anomalies reveal a noisy and high-frequency pattern (blue), which has been smoothed using a 12-month running mean (black). For meridional and zonal transports, the corresponding statistics using monthly anomalies from Fig. 3 are found in Table 1. Few in situ analyses have utilized long-term depth-integrated transports for the SO owing to the lack of surface-to-bottom estimations.

Using the ECCO state estimate as a tool, there are no trends significantly different from zero within the depth-integrated zonal and meridional transports at the defined basin boundaries indicated in Fig. 2. This indicates the trends are statistically insignificant in the SO mean-flow basin transports from 1992 to 2015 (Table 1). In the Atlantic, the least squares linear regression slope at the $95 \%$ confidence interval is $0.0751 \pm$ $0.0947 \mathrm{~Sv}_{\text {decade }}{ }^{-1}(p=0.119)$, the Indian basin slope

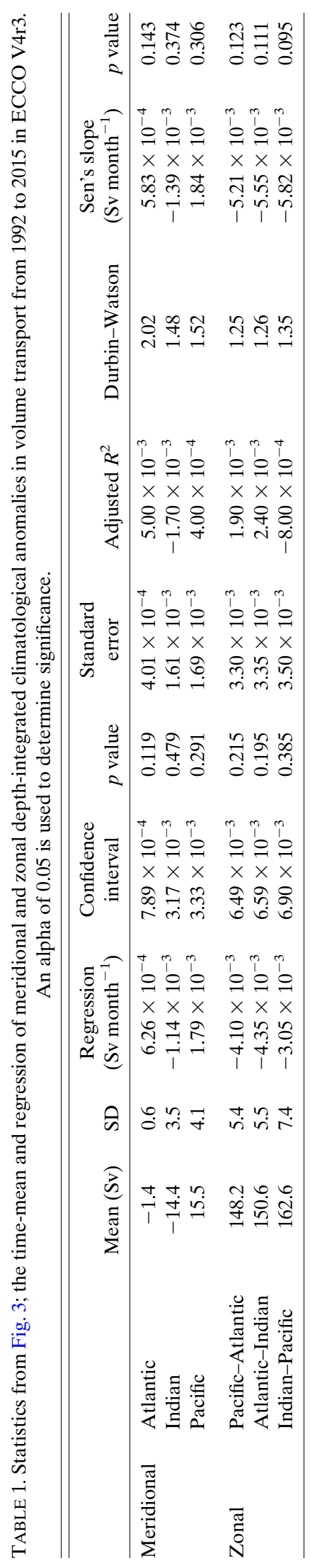




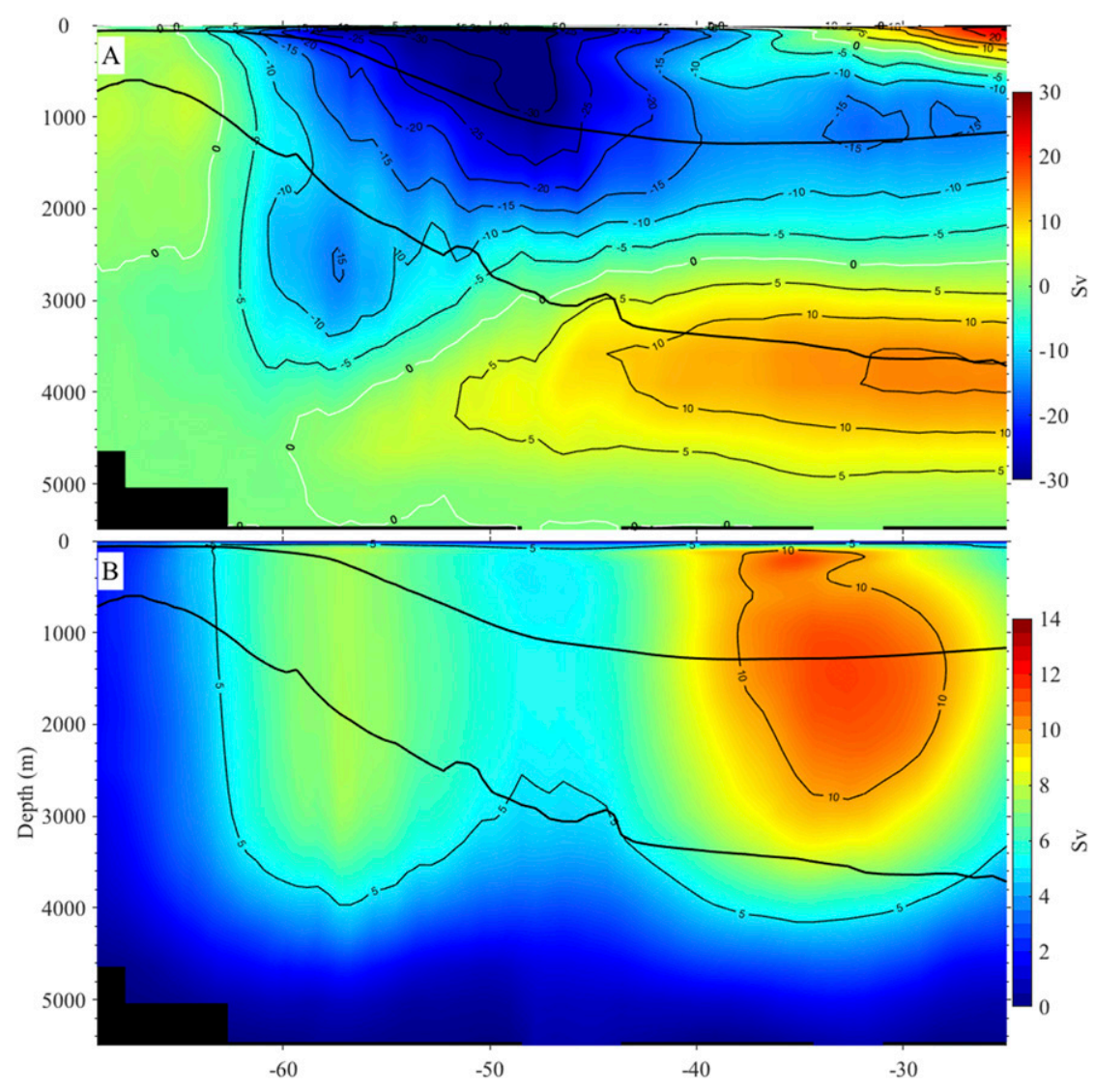

FIG. 4. (a) Time-mean SO overturning streamfunction between $25^{\circ}$ and $70^{\circ} \mathrm{S}$. Positive (negative) values denote counterclockwise (clockwise) circulation. (b) The standard deviation is estimated for the entire 288-month state estimate. The black lines are the 27.72 and $28.11 \mathrm{~kg} \mathrm{~m}^{-3}$ neutral-density surfaces to depict the branches of the two global meridional overturning cells.

is $-0.137 \pm 0.380 \mathrm{~Sv}^{2}$ decade $^{-1}(p=0.479)$, and the Pacific basin is $0.215 \pm 0.399 \mathrm{~Sv}_{\text {decade }}^{-1}(p=0.291)$. While regressions indicate similar-facing trends in the Pacific and Indian basins, and an opposing trend in the Atlantic basin, the $p$ values are greater than 0.05 , and thus the slopes are not significantly different from zero. The statistical analyses therefore present no evidence of a change in the Atlantic MOC or Indo-Pacific transports. Although the trends are approximately zero, the largest variability in the meridional transports exists in the Indian and Pacific basins. This variability is shown through the standard deviations within Fig. 2 and the standard errors from Table 1. Moreover, the Atlantic basin exhibits the lowest variability of meridional transports across $30^{\circ} \mathrm{S}$.

In the SO, the ACC dominates zonal transports, with a mean eastward flow. The Drake Passage, Atlantic-Indian, and Indian-Pacific exchange indicate rates of $-0.492 \pm$ $0.778 \mathrm{~Sv}_{\text {decade }}{ }^{-1}(p=0.215),-0.522 \pm 0.790 \mathrm{~Sv}^{-}$decade $^{-1}$ $(p=0.195)$, and $-0.366 \pm 0.828 \mathrm{~Sv}$ decade $^{-1}(p=0.385)$, respectively. While analyses indicate negative trends (Table 1), the $p$ values indicate the slopes are statistically insignificant and thus present no evidence to support that zonal transports are decreasing with time. The results from Fig. 3 further indicate that all three zonal basin exchanges have similar variability, shown through the standard errors (Table 1).

The time-mean MOC streamfunction (Fig. 4a) displays the strong Ekman-driven transport within the SO peaking near $50^{\circ} \mathrm{S}$. Each of the overturning cells transports roughly $15 \mathrm{~Sv}$ in the meridional component, at the 27.72 and $28.11 \mathrm{~kg} \mathrm{~m}^{-3}$ surfaces at $30^{\circ} \mathrm{S}$. The large monthly variability in the MOC on depth coordinates (Fig. 4b) supports using density coordinates in analysis of volume transports in the SO, further described in Lee and Coward (2003). Near $30^{\circ} \mathrm{S}$, the streamfunction exhibits large variability within the surface to over 3000-m depth, while depths over $4500 \mathrm{~m}$ display minimal variability. Comparing the transports of the SO along density coordinates reduces 


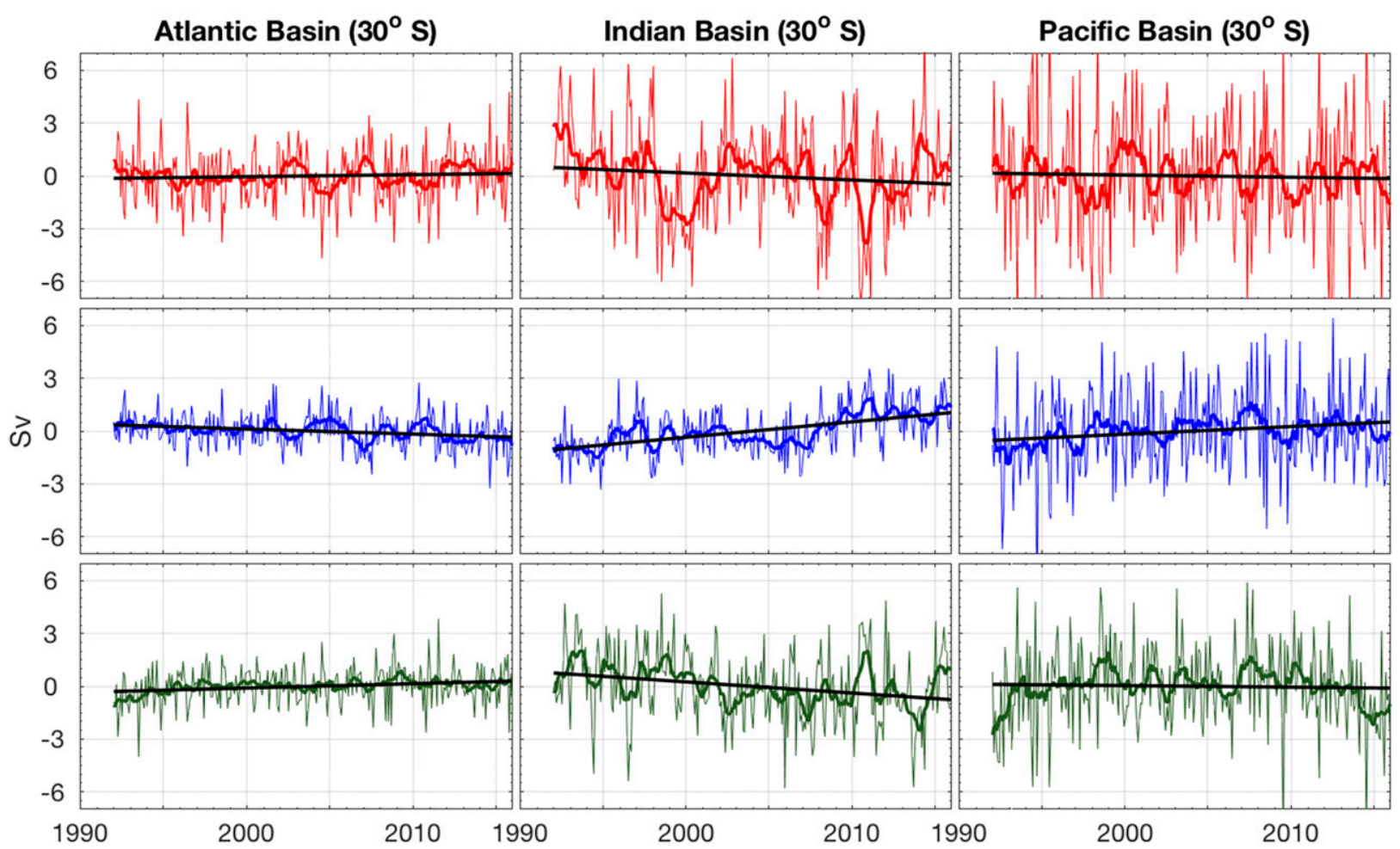

FIG. 5. Monthly climatological anomalies of neutral density-integrated meridional transports, the 12-month running mean (thick line), and regression line (black). The statistics are found in Table 2. Red represents the upper, blue the middle, and green the bottom branch of the overturning circulation. The meridional transport is estimated across $30^{\circ} \mathrm{S}$ and binned based on 27.72 and $28.11 \mathrm{~kg} \mathrm{~m}^{-3}$ neutral-density surfaces.

variability, as the meridional transports are largely associated with isopycnals rather than depth. Within the density-coordinate MOC, there are three distinct branches of overturning separated by the 27.72 and $28.11 \mathrm{~kg} \mathrm{~m}^{-3}$ surfaces. Working in density coordinates allows for a more thorough analysis into changes within the water column. To better comprehend and analyze the SO transports, a similar comparison of depth-integrated transports is applied to density coordinates for the meridional component.

\section{b. Density-integrated volume transports}

In comparison to neutral-density-integrated transports, ECCO provides similar results to that of both Ganachaud and Wunsch (2000) and Mazloff et al. (2010). Within ECCO (Fig. 2), the Atlantic basin time-mean northward transport in the top branch is $13.9 \pm 2.4 \mathrm{~Sv}$ and $1.8 \pm 1.5 \mathrm{~Sv}$ in the bottom, while southward transport in the middle branch is $-17.1 \pm$ 1.4 Sv. In the Pacific basin, the top branch time mean has a northward transport of $14.1 \pm 7.5 \mathrm{~Sv}$ and $8.6 \pm$ $3.4 \mathrm{~Sv}$ in the bottom, while the middle transports southward at $-7.2 \pm 3.1 \mathrm{~Sv}$. The Indian basin has southward transports of $-14.4 \pm 4.0 \mathrm{~Sv}$ in the top branch and $-4.0 \pm 1.7 \mathrm{~Sv}$ in the middle, with northward transports of $4.0 \pm 4.2 \mathrm{~Sv}$ in the bottom.

To account for a temporal variability, Fig. 5 depicts the meridional climatological monthly anomalies (19922015), with statistical values in Table 2 . The Indian, Atlantic, and Pacific basin linear regressions estimate the slope of the meridional transport in the top branch to be $-0.395 \pm 0.455 \mathrm{~Sv}^{2}$ decade $^{-1}(p=0.098)$, $0.116 \pm 0.251 \mathrm{~Sv}^{2}$ decade $^{-1}(p=0.363)$, and $-0.127 \pm$ $0.557 \mathrm{~Sv}_{\text {decade }}{ }^{-1}(p=0.654)$, respectively. In each basin, the trend is statistically insignificant for the top branch. The middle branches in all three basins have $p$ values that indicate slopes are significantly different from zero. The Atlantic basin middle branch is significantly increasing in southward transport at $-0.289 \pm$ $0.160 \mathrm{~Sv}_{\text {decade }}^{-1}(p<0.001)$, while significantly decreasing at $0.878 \pm 0.196(p<0.001)$ and $0.436 \pm$ $0.384 \mathrm{~Sv}_{\text {decade }}-1 \quad(p=0.026)$ in net meridional transport within the Indian and Pacific basins, respectively. The lower branches of the Atlantic and Indian basins indicate results are statistically significant. The Atlantic basin bottom branch is significantly increasing in northward transport at $2.48 \pm 0.172 \mathrm{~Sv} \mathrm{decade}^{-1}(p=0.005)$, 


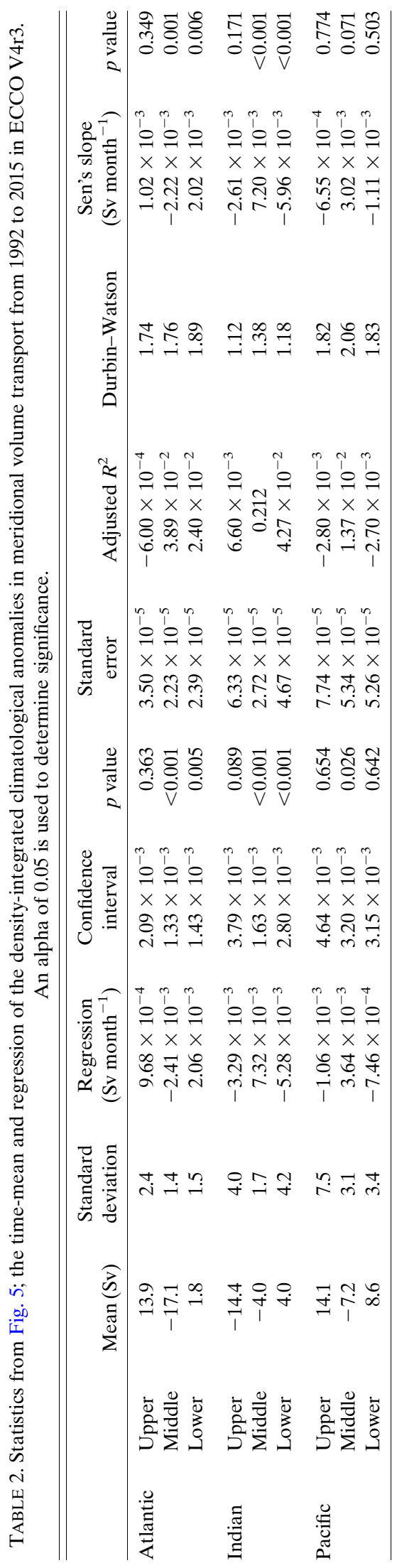

while the Indian is decreasing in northward transport at $-0.634 \pm 0.336 \mathrm{Svdecade}^{-1}(p<0.001)$. The Pacific basin bottom branch slope is statistically insignificant at $-0.0895 \pm 0.378 \mathrm{~Sv}$ decade $^{-1}(p=0.642)$. For a visual comparison of transports and trends, Fig. 2 includes the time-mean transports (Fig. 2a) and the trends in transports (Fig. 2b) that are significantly significant.

The temporal analysis of the meridional branches of the overturning cells' transports is used to explore the strength of the global overturning circulation. Within the Atlantic basin, the middle and lower branches are significantly increasing in magnitude at $95 \%$ confidence by $0.289 \pm 0.160$ (southward) and $0.248 \pm 0.172 \mathrm{~Sv}^{2} \mathrm{decade}^{-1}$ (northward). This would indicate a change in the $\mathrm{CDW}$ and $\mathrm{AABW}$ transports within the Atlantic basin and a statistically significant acceleration of the Atlantic portion of the global MOC lower cell, as both northward and southward transports are increasing trends. From section $3 a$, the Atlantic meridional transport trends were indicated to be statistically insignificant, whereas when using density to define the circulation, we find that the Atlantic transports are increasing in strength within the defined water masses.

Within the Indian and Pacific basins, the meridional depth-integrated transports are shown to be statistically insignificant; however, using density integration within the Indian basin, there are significant opposing trends in the middle branch southward transports and the bottom northward transports in the Indian basin. This indicates that there is a deceleration in the net density-defined volume transport in the lower cell of the overturning circulation. The $95 \%$ confidence intervals for the middle and bottom branches are $0.878 \pm$ 0.192 and $-0.634 \pm 0.336 \mathrm{~Sv}$ decade $^{-1}$, respectively. In the Pacific basin, there is a positive regression in the middle cell, a trend that opposes the southward direction of transports at $0.436 \pm 0.384 \mathrm{~Sv}_{\text {decade }}{ }^{-1}$. The significant negative trends found in the Indian and Pacific basins could indicate a deceleration in the $\mathrm{CDW}$ and $\mathrm{AABW}$ of the Indian and Pacific basin circulations, as there is a significant decline in the middle and lower branch transports associated with the global MOC.

In the Atlantic, the largest variability occurs within the top branch of the meridional transports. Moreover, compared to the Pacific and Indian basin meridional transports, the Atlantic has the lowest standard deviations and standard errors in transports. The Indian and Pacific basins similarly indicate the largest variability is within the surface waters but larger than that of the Atlantic. The Pacific basin has the largest variability in depth- and 


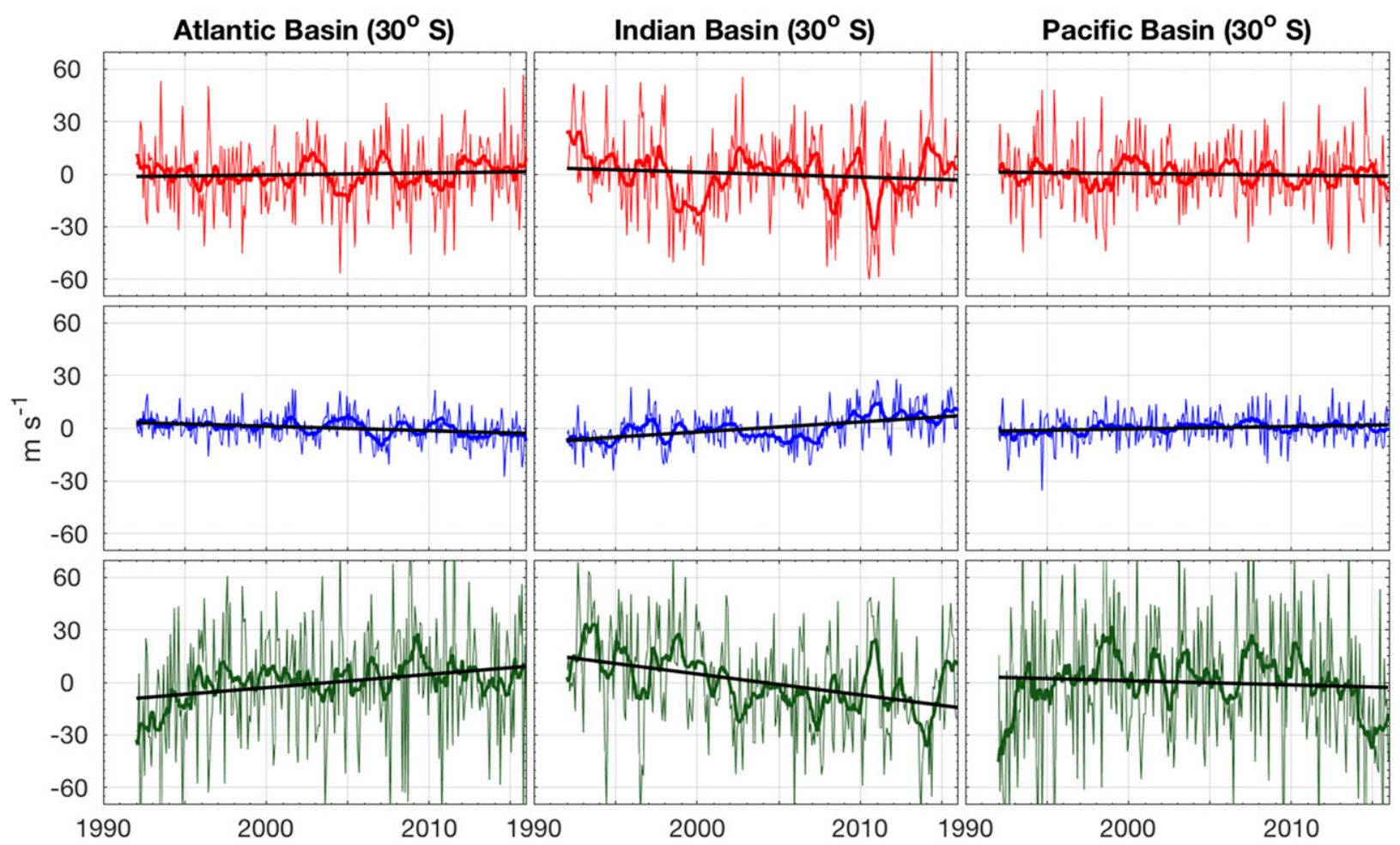

FIG. 6. Monthly climatological anomalies of net meridional velocity by density class at $30^{\circ} \mathrm{S}$ (transports standardized by the area), the 12-month running mean (thick line), and regression line (black). The statistics are found in Table 3. Red represents the upper, blue the middle, and green the bottom branch of the overturning circulation; binned based on 27.72 and $28.11 \mathrm{~kg} \mathrm{~m}^{-3} \mathrm{neutral-}$ density surfaces.

density-integrated transports and results in large residuals within the linear fit.

\section{c. Standardized density-integrated volume transports}

The statistical results in section $3 b$ indicate significant changes within the density-integrated volume transports. To further analyze the changes within the density classes, the area of each of the three branches of the meridional circulation is used to standardize the volume transport $\left(\mathrm{Sv} \mathrm{m}^{-2}\right)$. Meridional transports are divided by the area of each branch at $30^{\circ} \mathrm{S}$ for the Atlantic, Indian, and Pacific basins, and units are converted to be in terms of velocity $\left(\mathrm{m} \mathrm{s}^{-1}\right)$. Standardizing the transports into velocity better accounts for variability in the amount of each the three water masses. The results (Fig. 6; Table 3), again, indicate significant changes within the meridional velocities. The Atlantic basin middle branch shows a significantly increasing southward velocity at $-2.56 \pm 1.33 \mathrm{~m} \mathrm{~s}^{-1}$ decade $^{-1}(p<$ 0.001 ), while the bottom branch shows a significantly increasing northward velocity at $7.61 \pm 5.36 \mathrm{~m} \mathrm{~s}^{-1}$ decade $^{-1}$ $(p=0.006)$. In section $3 b$, the slopes of increase within the middle and bottom branches of the Atlantic basin were similar in magnitude, whereas when standardized for area, the bottom branch velocity is increasing nearly 3 times faster than the middle branch. This difference illustrates the significant increase in the AABW northward transports out of the SO and increase of the lower cell circulation from 1992 to 2015 .

The Indian basin demonstrates the middle branch shows significantly decreasing southward velocity at $5.79 \pm 1.56 \mathrm{~m} \mathrm{~s}^{-1}$ decade $^{-1}(p<0.001)$, while the bottom branch shows a significantly decreasing northward velocity at $-12.0 \pm 4.68 \mathrm{~m} \mathrm{~s}^{-1}$ decade $^{-1}(p<0.001)$. The Pacific basin shows a further decreasing southward velocity in the middle branch at $1.47 \pm 1.38 \mathrm{~m} \mathrm{~s}^{-1}$ decade $^{-1}(p<$ $0.037)$. These results further imply significant changes within the Indian and Pacific basins, decreasing meridional circulation in the middle and bottom branches of the $\mathrm{MOC}$ at $30^{\circ} \mathrm{S}$.

Within Fig. 6 and Table 3, the largest variability in each basin exists in the bottom branch of the transports, while the lowest variability exists in the middle branch. This suggests the circumpolar deep waters maintain relatively low variability in velocity in each basin, while the bottom waters exhibit the greatest variability. Despite changes in the area of 


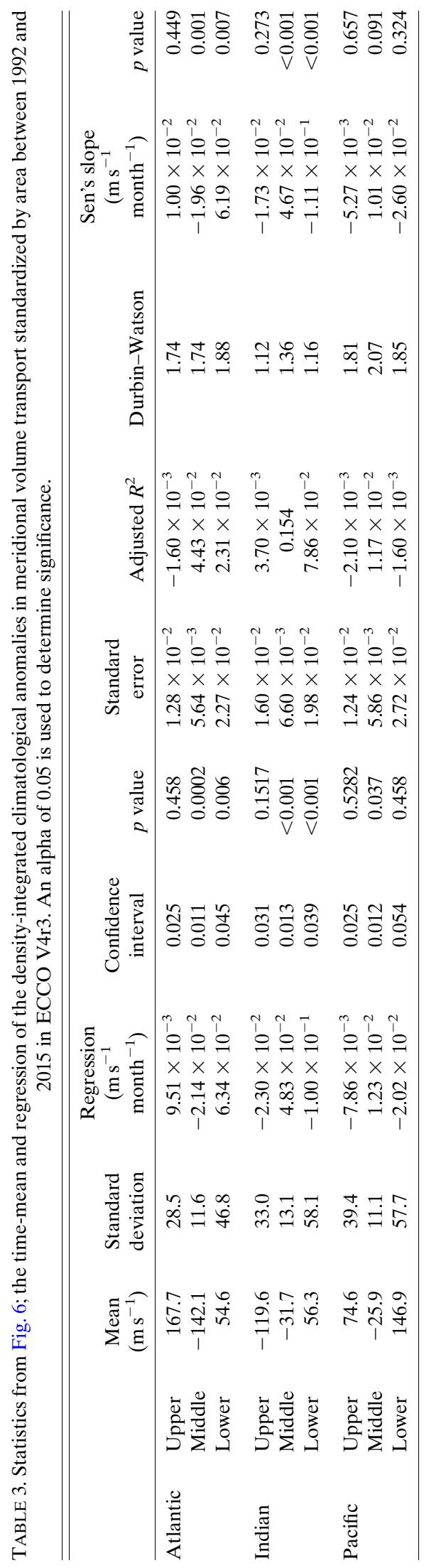

transports across $30^{\circ} \mathrm{S}$, trends within the Atlantic, Indian, and Pacific basin velocities are significantly changing.

\section{d. Depth-integrated temperature and salt transports}

The meridional transports of potential temperature and salinity and the regression are plotted as a function of latitude between 1992 and 2015 (Fig. 7; Table 4). The net transport is decomposed into the advective and diffusive components, which account for deviations from the mean. In the SO, there is a net poleward transport of both temperature and salinity. The temperature transports (Fig. 7a) are mainly driven by advection near the subtropical and polar regions, influenced by gyre circulation, but are balanced by both advective and diffusive forces in the ACC region. The decadal trend in temperature transport (Fig. 7c) shows trends opposing the direction of net, diffusive, and advective transports in the polar region, indicating the transports poleward of $60^{\circ} \mathrm{S}$ are decreasing. The subtropical region indicates increasing gyre transports, and the ACC region depicts the southward movement of the maximum advective, net, and diffusive transports of temperature. Salinity transports (Fig. 7b) are a balance of the advective and diffusive terms, with southward transport throughout the SO. The lowest mean fluxes occur near the subtropical and polar gyre, while the greatest difference in the two components appears in the ACC region. The decadal trends (Fig. 7d) indicate opposing trends to both advective and diffusive components, which relates to increasing southward net transport trend in the subtropical and polar regions and decreasing southward net transport in the ACC region.

Regional meridional depth-integrated transports of salinity and temperature are further analyzed (Fig. 8; Table 4). The $95 \%$ confidence interval of time-mean temperature transport across $30^{\circ} \mathrm{S}$ in the Atlantic basin is $70.1^{\circ} \pm 43.3^{\circ}(\sim 0.3 \mathrm{PW})$ and $70.8^{\circ} \pm 122.3^{\circ} \mathrm{C} \mathrm{Sv}$ $(\sim 0.3 \mathrm{PW})$ in the Pacific basin. There is a net southward transport of $-317.2^{\circ} \pm 73.2^{\circ} \mathrm{C} \mathrm{Sv}(\sim-1.3 \mathrm{PW})$ in the Indian basin. The net transport across $30^{\circ} \mathrm{S}$ is roughly $-176.2^{\circ} \pm 197.2^{\circ} \mathrm{C} \mathrm{Sv}(\sim-0.7 \mathrm{PW})$, southward into the SO (Fig. 7a). The ECCO estimates larger temperature transports in the Atlantic and Indian basins than that of Mazloff et al. (2010), but lower values for the Pacific basin, but estimates similar variability to Mazloff et al. (2010). The estimates are similar to those of Ganachaud and Wunsch (2000), Talley (2003), and Zheng and Giese (2009) but larger than those of Stammer et al. (2003) estimates. Estimates of temperature transports for the Atlantic basin by Mazloff et al. (2010) 


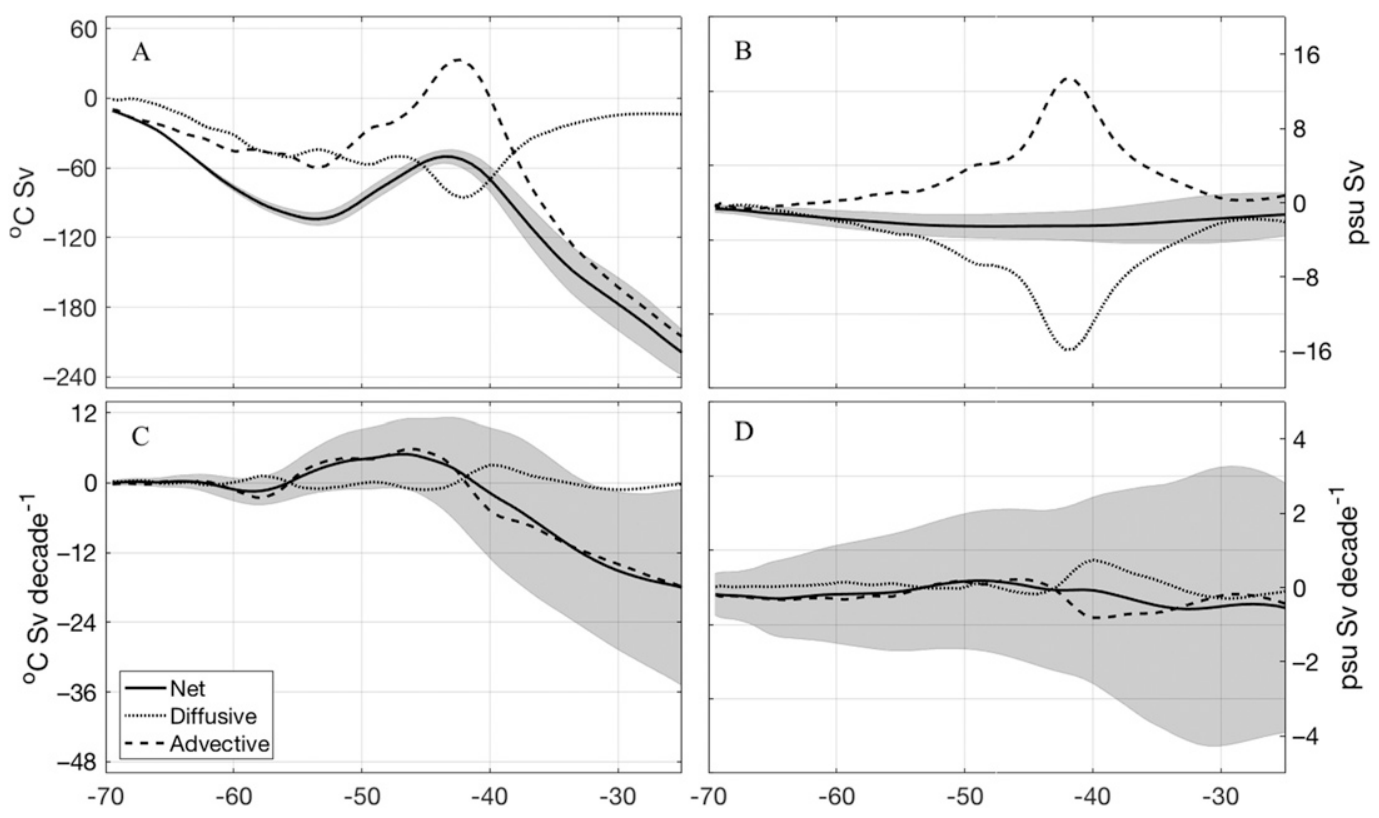

FIG. 7. Time-mean net, diffusive, and advective (a) potential temperature and (b) salinity transports for the SO, with the net time-mean outlined with the $95 \%$ confidence interval. Positive values are northward and negative values are southward transports. (c),(d) The monthly time regression $\left(\right.$ decade $^{-1}$ ) for each net, diffusive, and advective component. The net trend is contoured with the $95 \%$ confidence interval. Trends relate to the transports, where positive values indicate increasing northward transport or weakening southward flow.

are $99^{\circ} \pm 66^{\circ} \mathrm{C} \mathrm{Sv}$ and $0.3 \pm 2 \mathrm{PW}$ in Ganachaud and Wunsch (2000). The net temperature transport into the Indian and Pacific basins is estimated to be $-246.3^{\circ} \pm$ $172.0^{\circ} \mathrm{C} \mathrm{Sv}$, greater than $-180.0^{\circ} \pm 210^{\circ} \mathrm{C} \mathrm{Sv}$ of Mazloff et al. (2010).

The Atlantic and Pacific basin meridional transport trends (Table 4) are not significant. The Indian basin, however, is significantly increasing southward transport at a rate of $-8.72^{\circ} \pm 4.5^{\circ} \mathrm{C} \mathrm{Sv}$ decade ${ }^{-1}(p=$ $0.026)$, approximately $-0.0358 \mathrm{PW}$ decade $^{-1}$. The net potential temperature depth-integrated transports across $30^{\circ} \mathrm{S}$ indicate a significant trend. The $95 \%$ confidence level of the meridional trend across $30^{\circ} \mathrm{S}$ from Fig. $7 \mathrm{a}$ is $-15.0^{\circ} \pm 13.5^{\circ} \mathrm{C} \mathrm{Sv}$ decade $^{-1}(p=0.030)$, approximately $-0.0615 \mathrm{PW} \mathrm{decade}{ }^{-1}$. This indicates that there is a significantly positive trend of southward potential temperature transports into the SO. In this analysis, the results suggest that there is an increasing net potential temperature transport into the SO from 1992 to 2015.

Meridional depth-integrated salinity transports trends are not significant within the SO. The time-mean and standard deviation salinity transport is $-32.9 \pm$ 21.7 psu Sv southward in the Atlantic and $-509.0 \pm$ $122.4 \mathrm{psu} \mathrm{Sv}$ in the Indian basin. The Pacific basin is estimated to be $540.3 \pm 140.6 \mathrm{psu}$ Sv northward.
The large southward transport of salinity from the Indian basin results from the large-scale evaporation in Indian Ocean (Talley 2008). The time-mean SO salinity transport across $30^{\circ} \mathrm{S}$ is $-1.7 \pm 22.4 \mathrm{psu} \mathrm{Sv}$. The regressions for salinity transports are not significant, and we can therefore conclude the net salinity transports across $30^{\circ} \mathrm{S}$ in the $\mathrm{SO}$ are not significantly changing from 1992 to 2015.

\section{e. Density-integrated temperature and salt transports}

Density-integrated salinity and potential temperature transports are further analyzed in a similar manner to that in section 3b. Using ECCO (Fig. 9 and Table 5), the Atlantic basin time-mean and standard deviation northward transport in the top branch is $120.1^{\circ} \pm 47.4^{\circ} \mathrm{C} \mathrm{Sv}$ and the bottom branch is $0.9^{\circ} \pm 1.6^{\circ} \mathrm{C} \mathrm{Sv}$, while southward transport in the middle is $-50.9^{\circ} \pm 3.8^{\circ} \mathrm{C} \mathrm{Sv}$. The Indian basin has southward transports of $-309.3^{\circ} \pm 78.1^{\circ} \mathrm{C} \mathrm{Sv}$ in the top and $-10.3^{\circ} \pm 3.9^{\circ} \mathrm{C} \mathrm{Sv}$ in the middle branches, with northward transports of $2.5^{\circ} \pm 3.5^{\circ} \mathrm{C} \mathrm{Sv}$ in the bottom branch. In the Pacific basin, the top branch time mean has a northward transport of $77.9^{\circ} \pm$ $127.9^{\circ}$ and $6.4^{\circ} \pm 2.5^{\circ} \mathrm{C} \mathrm{Sv}$ in the bottom, while the middle branch transports southward at $-13.5^{\circ} \pm$ $5.5^{\circ} \mathrm{C} \mathrm{Sv}$. These values demonstrate the large southward 


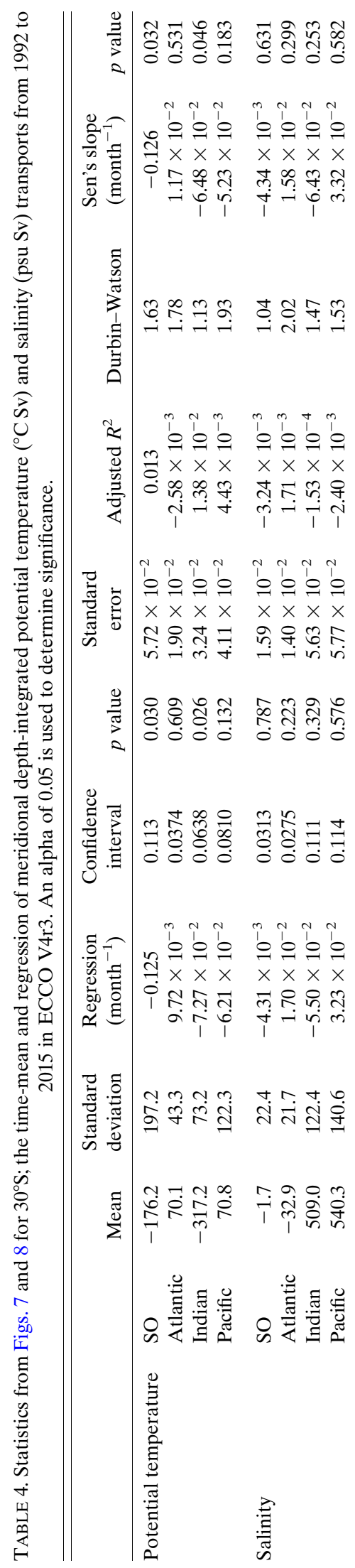

transport of potential temperature within the surface waters of the Indian Ocean and the high variability of the Pacific Ocean surface transports.

Least squares linear regressions indicate significant trends within the SO basins. The Atlantic basin middle branch is increasing southward transports at a $95 \%$ confidence of $-1.86^{\circ} \pm 0.432^{\circ} \mathrm{Cdecade}^{-1}(p<0.001)$ and northward transports in the bottom branch at $0.31^{\circ} \pm 0.19^{\circ} \mathrm{C} \mathrm{Svdecade}{ }^{-1}(p=0.001)$. The top branch of the Indian basin shows a significant increase in southward transports at $-10.29^{\circ} \pm 8.0^{\circ} \mathrm{C}$ Sv decade ${ }^{-1}(p=0.012)$ but a decrease of $1.98^{\circ} \pm$ $0.43^{\circ} \mathrm{C} \mathrm{Sv}$ decade $^{-1}(p<0.001)$ in the middle branch and northward transports by $-0.41^{\circ} \pm 0.28^{\circ} \mathrm{C} \mathrm{Sv}$ decade $^{-1}$ $(p=0.004)$ in the bottom branch. The middle branch of the Pacific basin indicates a negative trend, decreasing southward transport by $0.80^{\circ} \pm 0.67^{\circ} \mathrm{C} \mathrm{Sv}$ decade $^{-1}$ $(p=0.020)$. These results agree with section $3 \mathrm{~b}$, that there is an acceleration of transports in the middle and bottom branches of the Atlantic and decline in the Indian and Pacific basins. However, the upper branch of the Indian basin shows a significant increase of southward transports of potential temperature, driving changes to the energy balance of the SO.

The Atlantic basin time-mean northward salinity transport (Fig. 10 and Table 5) in the top branch is $486.0 \pm 84.6 \mathrm{psu} \mathrm{Sv}$ and the bottom branch is $71.9 \pm 51.6 \mathrm{psu}$ Sv, while southward transport in the middle branch is $-590.9 \pm 48.2 \mathrm{psu}$ Sv. The Indian basin has southward salinity transports of $-511.4 \pm$ $141.1 \mathrm{psu} S v$ in the top and $-141.7 \pm 58.0 \mathrm{psu} \mathrm{Sv}$ in the middle branch, with northward transports of $143.5 \pm$ $143.9 \mathrm{psu} \mathrm{Sv}$ in the bottom branch. In the Pacific basin, the top branch time-mean has a northward salinity transport of $474.4 \pm 260.2$ psu Sv and $299.7 \pm$ 116.5 psu Sv in the bottom, while the middle branch transports southward at $-234.0 \pm 105.4 \mathrm{psu}$ Sv.

In each basin, the top branch has slopes that are not significant and thus have no linear trends in salinity transports. The Atlantic basin middle branch shows an increasing southward transport at a rate of $-10.26 \pm$ 5.5 psu Sv decade ${ }^{-1}(p<0.001)$ and northward transports in the bottom at $8.06 \pm 5.4$ psu Sv decade ${ }^{-1}(p=$ $0.008)$. The middle branch of the Indian basin is significantly decreasing in southward transports at $30.43 \pm$ 6.8 psu Sv decade ${ }^{-1}(p<0.001)$ and the bottom branch northward transports by $-23.03 \pm 11.6 \mathrm{psu} \mathrm{Sv}$ decade $^{-1}$ $(p<0.001)$. The middle branch of the Pacific basin shows decreasing southward transport by $14.76 \pm$ 13.2 psu Sv decade ${ }^{-1}(p=0.028)$. Similar to the transports in section $3 \mathrm{~b}$, the density-integrated salinity transports support increasing circulation within the middle and 

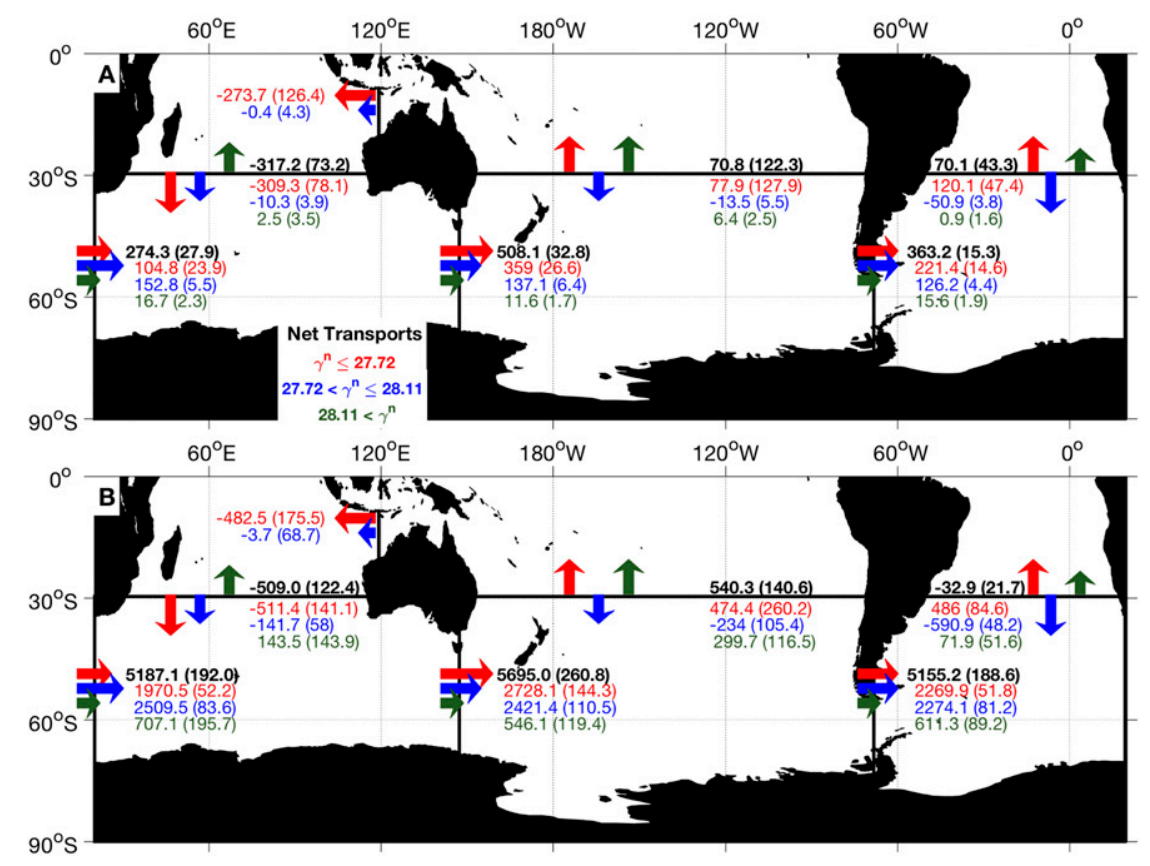

FIG. 8. ECCO's 24-yr time-mean depth-integrated net potential (a) temperature $\left({ }^{\circ} \mathrm{C} \mathrm{Sv}\right)$ and (b) salinity (psu Sv) transports and monthly standard deviations (in parentheses) across each of the basins. Red $\left(\gamma^{n} \leq 27.72 \mathrm{~kg} \mathrm{~m}^{-3}\right)$ represents the surface and mode waters, blue $\left(27.72 \mathrm{~kg} \mathrm{~m}^{-3}\right.$ $\left.<\gamma^{n} \leq 28.11 \mathrm{~kg} \mathrm{~m}^{-3}\right)$ the CDW, and green $\left(\gamma^{n}>28.11 \mathrm{~kg} \mathrm{~m}^{-3}\right)$ the AABW. The AtlanticIndian Ocean border is defined as $20^{\circ} \mathrm{E}$, the Indian-Pacific border at $145^{\circ} \mathrm{E}$, and the PacificAtlantic border at $70^{\circ} \mathrm{W}$. The meridional transport is estimated across $30^{\circ} \mathrm{S}$. The estimate for the meridional transport through the Bering Strait is $0.9 \pm 0.5 \mathrm{~Sv}$ from the Pacific to the Atlantic Ocean.

bottom branches in the Atlantic and decreasing within the Indian and Pacific cells.

\section{f. Mechanisms for density-integrated transport changes}

Salinity, temperature, and density trends are estimated through a least squares linear fit of the climatological anomalies, removing seasonality (Fig. 11). Long-term decadal changes in the SO's temperature and salinity have been previously shown (Gille 2002, 2008; Durack and Wijffels 2010). These results demonstrate broadscale warming throughout much of the midlatitudes in all three basins and the high latitudes of the Atlantic and Indian Ocean basins, while there is cooling in much of the ACC regions of the Atlantic and Indian basins and poleward of $50^{\circ} \mathrm{S}$ in the Pacific basin. The high-latitude warming in the Atlantic and Indian basins reach depths near $4000 \mathrm{~m}$, far below the surface.

Within the Atlantic and Indian basins, salinity trends correspond to similar regions and magnitudes as temperature trends, although with greater trends within the high-latitude bottom waters. The Pacific basin illustrates broadscale freshening throughout much of the surface
SO, while it shows increasing salinity in the high latitudes. Compared to the other basins, the bottom waters in the Pacific have weaker trends that are not significant. Our results show there are large-scale changes in temperature and salinity values from the surface to the ocean bottom within the Indian and Atlantic basins, while there are only significant changes within the surface $1000 \mathrm{~m}$ of the Pacific basin.

In both the Atlantic and Indian basins, similar highlatitude regions illustrate a positive trend in temperature and a negative trend in density, despite a significant increase in salinity. Outside the surface waters and the high-latitude Pacific basins, much of the changes in density correspond with changes in temperature. This is important to consider as both the Indian and Pacific basins' CDW potential temperature trends imply a decrease in temperature transports out of the SO, but ECCO further indicates decreasing temperatures and increasing densities within the middle branch of the basins. Within the Indian basin at $30^{\circ} \mathrm{S}$, the bottom branch shows a significant increase in temperatures and decrease in densities. Moreover, changes in density are statistically significant along the region of the $28.11 \mathrm{~kg} \mathrm{~m}^{-3}$ time-mean isopycnal, which indicates 


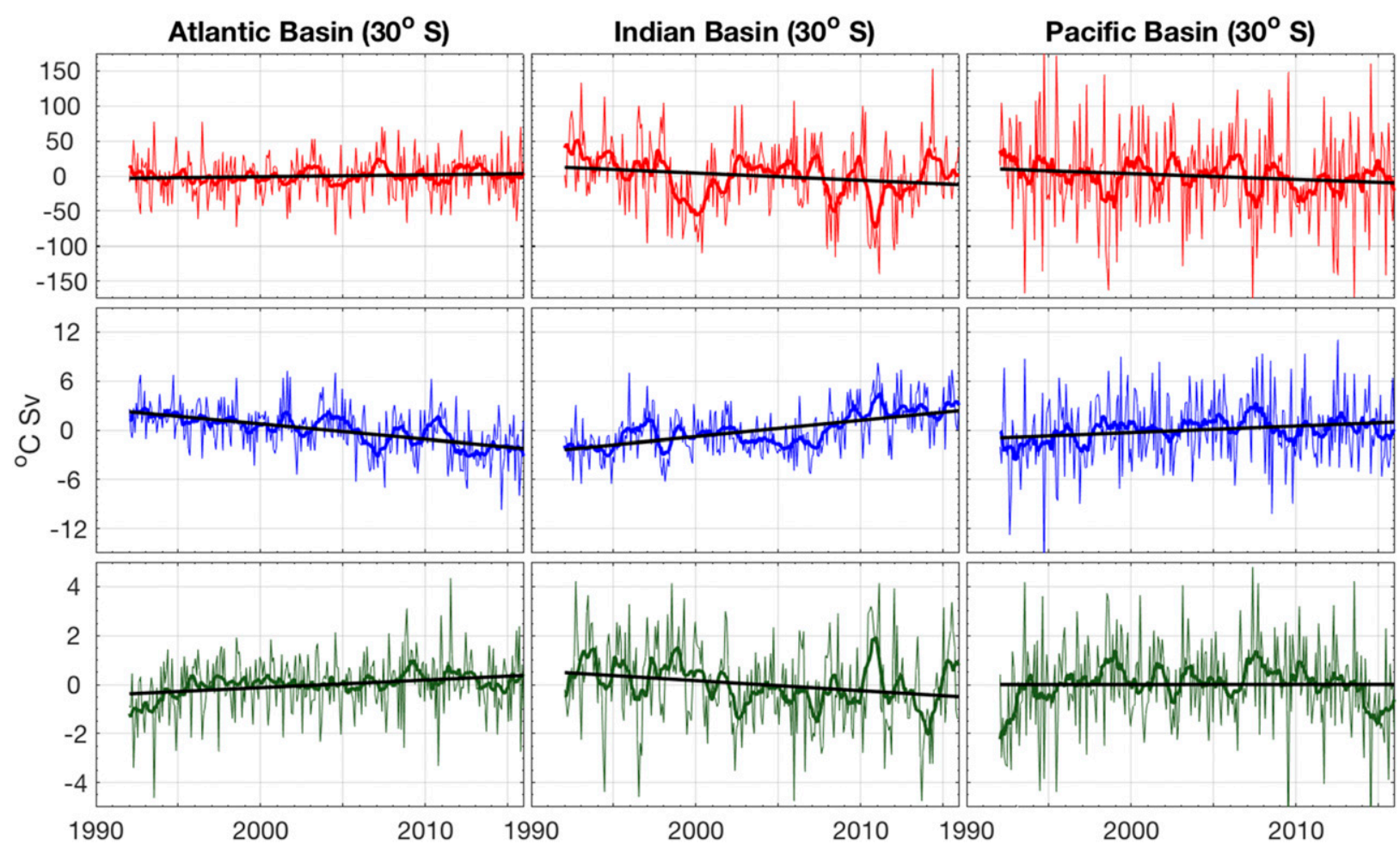

FIG. 9. Monthly climatological anomalies of neutral-density-integrated meridional temperature transports, the 12-month running mean (thick line), and regression line (black). The statistics are found in Table 5. Red represents the upper, blue the middle, and green the bottom branch. The meridional transport is estimated across $30^{\circ} \mathrm{S}$ and binned based on 27.72 and $28.11 \mathrm{~kg} \mathrm{~m}{ }^{-3} \mathrm{neutral}$ density surfaces.

water masses are changing density over time. Each basin indicates significant changes of density in regions around the 27.72 and $28.11 \mathrm{~kg} \mathrm{~m}^{-3}$ time-mean isopycnals (Fig. 12), except the $28.11 \mathrm{~kg} \mathrm{~m}^{-3}$ neutraldensity surface in the Atlantic. These results imply a significant increase within the area of intermediate and mode waters of all three basins and within AABW of the Pacific and Indian basins at $30^{\circ} \mathrm{S}$. Moreover, there is a significant decrease in the area of the CDW within all three basins.

The change in density classes may drive the decrease in the density-integrated transports within the Indian and Pacific basins. However, when standardizing for area of each density class, the meridional transports within the middle and bottom branches are shown to be decreasing. This could be as a result from changes in the amount of each water mass class or a proxy of circulation changes. The Atlantic basin poses a more interesting result, where the AABW is the only branch to not have a significant trend. This implies the area across $30^{\circ} \mathrm{S}$ where AABW is transported in the Atlantic basin is not significantly changing between 1992 and 2015. Our analysis indicates the lower branch of the Atlantic MOC is accelerating, while the Indian and Pacific basins are decreasing in transports.

\section{Conclusions}

Through the use of ECCO, the SO variability and trends of depth- and density-integrated zonal and meridional transports are examined throughout a $24-\mathrm{yr}$ period. Trends of zonal transport between all three basins are statistically insignificant. The net Drake Passage volume transport is estimated to be $148.2 \pm 5.3 \mathrm{~Sv}$, the Atlantic-Indian basin transport is $150.6 \pm 5.5 \mathrm{~Sv}$, and Indian-Pacific is $162.6 \pm 7.4 \mathrm{~Sv}$. Similar values are found in many previous studies (e.g., Ganachaud and Wunsch 2000; Mazloff et al. 2010) but transports are larger than previous observational analyses (i.e., Stammer et al. 2003). We have expanded on these results to show trends in net zonal transports are not significantly different from zero between the SO basins from 1992 to 2015. The depth-integrated meridional transport trends are further not statistically different from zero. The Indian basin has net southward transport of $-14.4 \pm 3.5 \mathrm{~Sv}$, the Pacific basin net northward transport of $15.5 \pm 4.1 \mathrm{~Sv}$, and the 


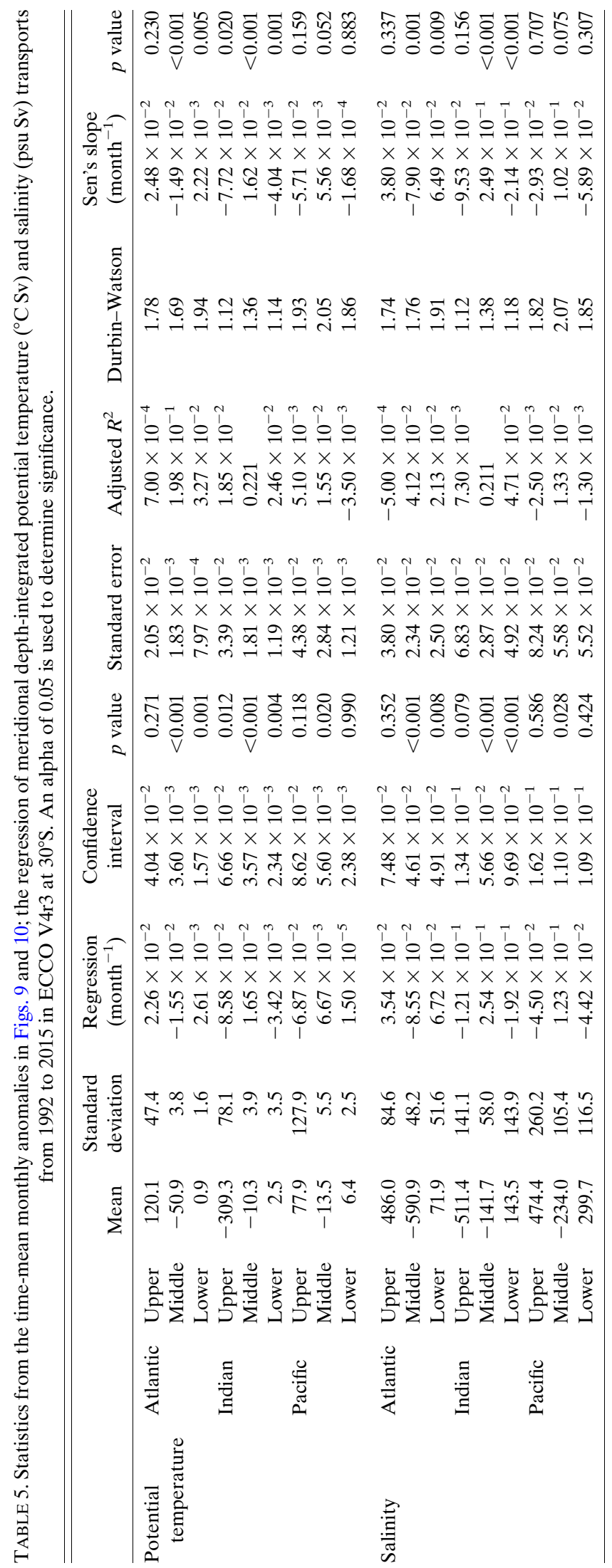




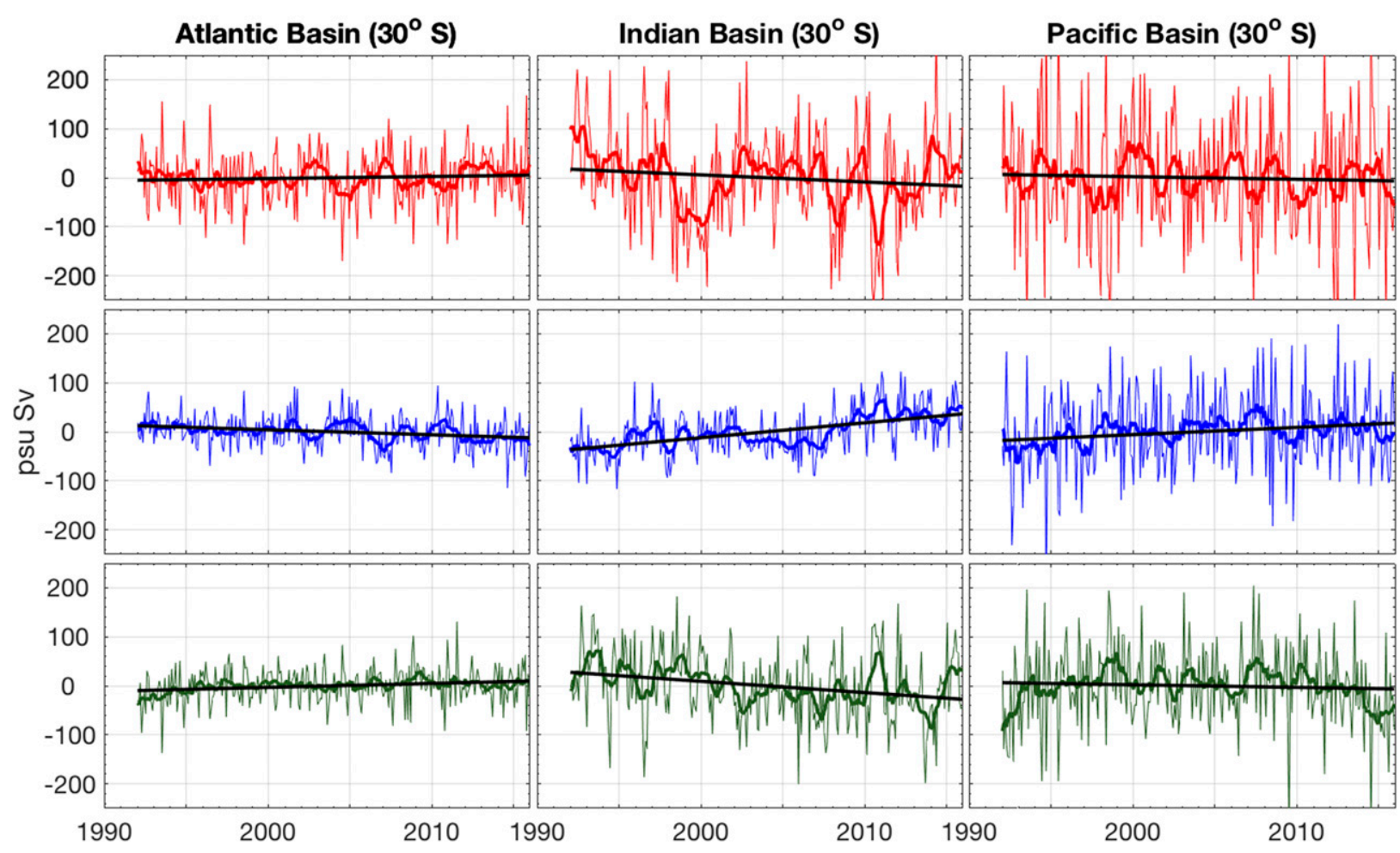

FIG. 10. Monthly climatological anomalies of neutral-density-integrated meridional salinity transports, the 12-month running mean (thick line), and regression line (black). The statistics are found in Table 5. Red represents the upper, blue the middle, and green the bottom branch. The meridional transport is estimated across $30^{\circ} \mathrm{S}$ and binned based on $27.72 \mathrm{and}_{28.11 \mathrm{~kg} \mathrm{~m}}^{-3} \mathrm{neutral-}$ density surfaces.

Atlantic basin has an estimated $-1.4 \pm 0.6 \mathrm{~Sv}$ southward. Initial results indicate that there are no significant changes within the Atlantic MOC transports or the Indian and Pacific sector of the MOC.

The meridional transports were further separated into the upper, middle, and lower branches of the MOC by density classes to provide a more accurate representation of the meridional transports. Our estimates of the various transports are within reason with regard to previous studies but include transport trends. The Atlantic basin time-mean transports are $13.9 \pm 2.4,-17.1 \pm 1.4$, and $1.8 \pm 1.5 \mathrm{~Sv}$ for the top, middle, and bottom branches, respectively. The Indian basin time-mean meridional transports are $-14.4 \pm 4.0,-4.0 \pm 1.7,4.0 \pm 4.2 \mathrm{~Sv}$, and those in the Pacific are $14.1 \pm 7.5,-7.2 \pm 3.1$, and $8.6 \pm 3.4 \mathrm{~Sv}$. Trends in the Atlantic basin indicate a significant acceleration in the bottom branch northward transports $\left(0.248 \pm 0.172 \mathrm{~Sv}\right.$ decade $\left.^{-1}\right)$ and the middle branch southward transports $\left(-0.289 \pm 0.160 \mathrm{~Sv}\right.$ decade $\left.^{-1}\right)$. The area of the density classes further implies the bottom water area across $30^{\circ} \mathrm{S}$ is not significantly changing over time. The estimated trends indicate a significant increase in the Atlantic basin lower cell overturning within the $\mathrm{SO}$, as $\mathrm{CDW}$ and $\mathrm{AABW}$ transports are increasing within a consistent area.

The acceleration in the South Atlantic is opposed by the Indian and Pacific sector. The Indian and Pacific basin branches of the MOC have trends that oppose the direction of transport, significantly decreasing by $0.878 \pm 0.196$ and $0.436 \pm 0.384 \mathrm{~Sv}$ decade $^{-1}$ in the middle branches, respectively, and $-0.634 \pm 0.336 \mathrm{~Sv}$ decade $^{-1}$ in the lower branch of the Indian basin. However, analysis of the area implies a decrease in the area of CDW and increase in AABW, where the water masses could be switching the defined density classes to reduce transports. The opposing water mass trends indicate a significant deceleration in the lower cell water transport in the Indian and Pacific basins but could further be an artifact of the changing density classes.

The SO potential temperature and salinity transports are analyzed through the advective and diffusive components. Temperature transport trends indicate increased potential temperature being transported southward across $30^{\circ} \mathrm{S}$, increasing the right-hand side of the budget estimation. Potential temperature transports are mainly influenced by the gyres in the polar and subtropical regions mean flow but are strongly 

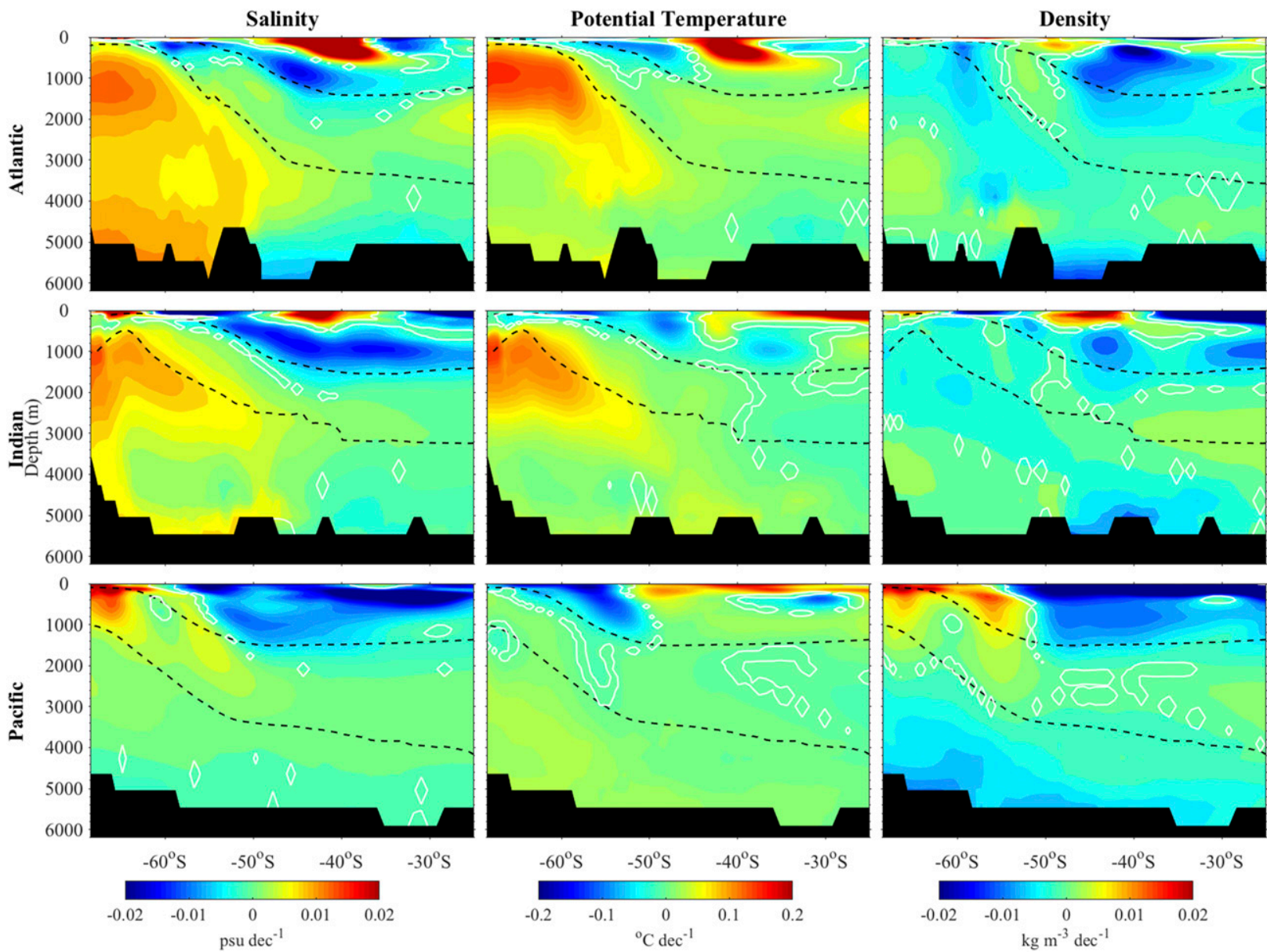

FIG. 11. Coefficients of regression for salinity, temperature, and density for each of the Atlantic, Indian, and Pacific basins. A least squares linear regression is used to fit the mean monthly anomaly for the variables between 1992 and 2015 . The regions within the white contour are not statistically significant $(p>0.05)$, and those contours outside are significant $(p<0.05)$. The dashed lines represent the time-mean 27.72 and $28.11 \mathrm{~kg} \mathrm{~m}^{-3}$ neutral-density surfaces between 1992 and 2015 for each respective basin.

influenced by the eddy component in the ACC region. Furthermore, the trends in the ACC region indicate a narrowing and southward shift of the eastward transports. Salinity transports are largely influenced by both mean-flow and diffusive properties at any given latitude but have opposing trends in both the advective and diffusive components. The Indian basin is significantly increasing net southward transports of potential temperature at a rate of $-8.72^{\circ} \pm 4.5^{\circ} \mathrm{C} \mathrm{Sv} \mathrm{decade}{ }^{-1}$, and combined there is an increasing trend of potential temperature transports into the $\mathrm{SO}$ at $-15.0^{\circ} \pm 13.5^{\circ} \mathrm{C}$ Sv decade ${ }^{-1}$. This indicates that the temperature transports are significantly increasing within the SO between 1992 and 2015, but there are no significant trends in the SO salinity transports.

The time-mean ECCO transports are consistent with many previous model-based and state estimates but are shown to estimate larger zonal transports than observational analyses. Through the use of ECCO, we find that the Atlantic MOC in the SO is accelerating, while the Indo-Pacific MOC is decreasing. Meridional transport trends additionally estimate significant changes in boundary current transports but could further be linked to a shift in midlatitude gyres. The initial hypothesis is that ECCO supports decreasing zonal and meridional depth-integrated transports in the SO. Monitoring and studying the exchange and transports of volume, heat, and salt all relate back to general circulation and the importance of the global MOC. Since the SO plays a fundamental role in balancing the downwelling waters of the North Atlantic, continuous monitoring of the SO MOC and ACC would allow for a better understanding of Earth's climate and advancing model potency. 


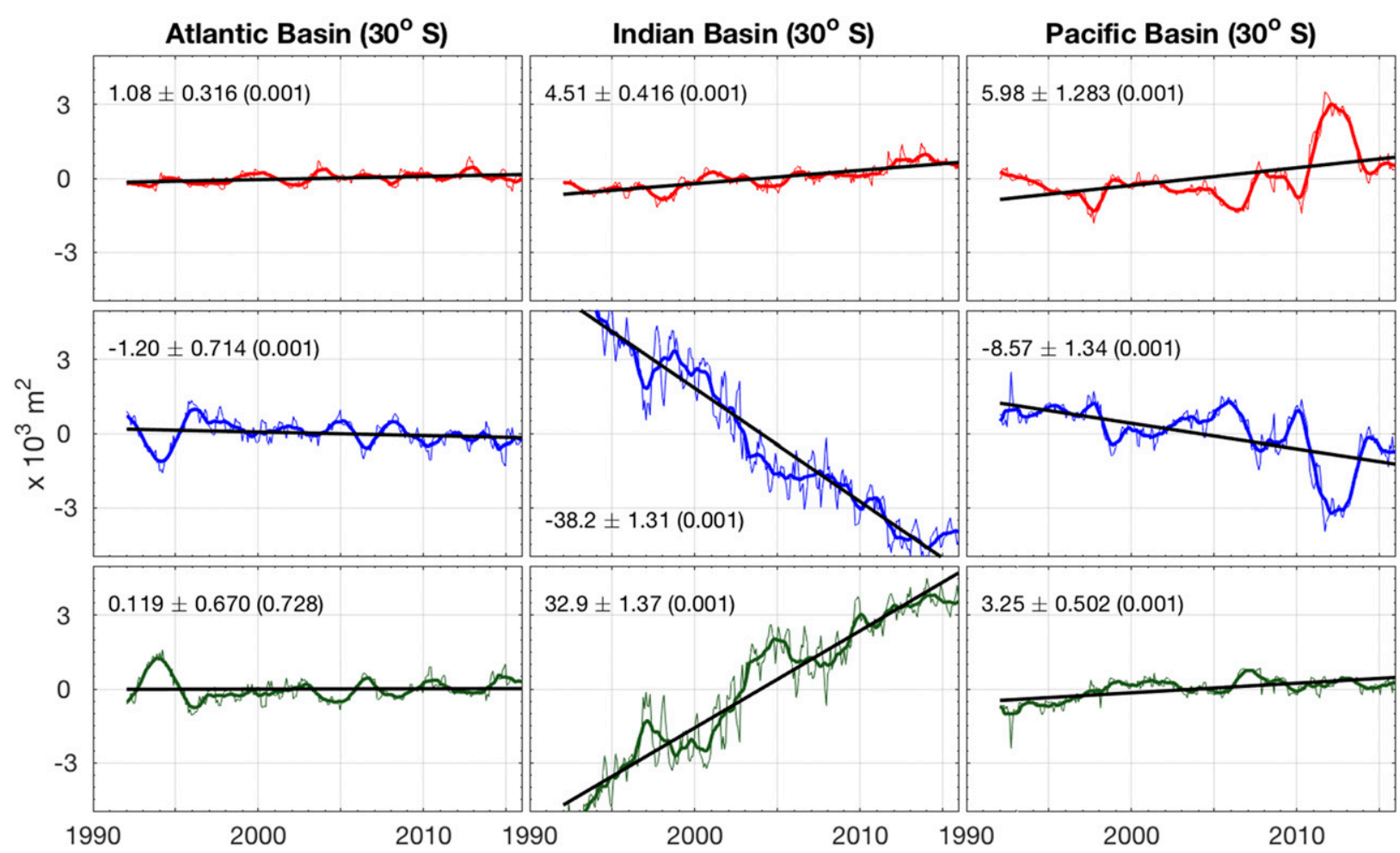

FIG. 12. Monthly climatological anomalies of the area of neutral-density-integrated meridional transports, the 12-month running mean (thick line), and regression line (black). Red represents the upper branch, blue the middle branch, and green the bottom branch. The meridional transport is estimated across $30^{\circ} \mathrm{S}$ and binned based on 27.72 and $28.11 \mathrm{~kg} \mathrm{~m}^{-3}$ neutral-density surfaces.

Acknowledgments. Brady Ferster is supported by the NASA South Carolina Space Grant Graduate Assistantship. Information on ECCO and its products can be found on the ECCO group webpage (http://www.ecco-group.org/products. htm). We thank Drs. Lynne Talley and Christopher Piecuch for their comments and suggestions. We would also like to thank the editor and anonymous reviewers for their insightful comments and suggestions.

\section{REFERENCES}

Beal, L. M., and S. Elipot, 2016: Broadening not strengthening of the Agulhas Current since the early 1990s. Nature, 540, 570 573, https://doi.org/10.1038/nature19853.

Bishop, S. P., P. R. Gent, F. O. Bryan, A. F. Thompson, M. C. Long, and R. Abernathey, 2016: Southern Ocean overturning compensation in an eddy-resolving climate simulation. J. Phys. Oceanogr., 46, 1575-1592, https://doi.org/10.1175/JPO-D-15-0177.1.

Böning, C. W., A. Dispert, M. Visbeck, S. R. Rintoul, and F. U. Schwarzkopf, 2008: The response of the Antarctic Circumpolar Current to recent climate change. Nat. Geosci., 1, 864-869, https:// doi.org/10.1038/ngeo362.

Buckley, M., and Coauthors, 2017a: A twenty-year dynamical oceanic climatology: 1994-2013. Part 1: Active scalar fields: Temperature, salinity, dynamic topography, mixed-layer depth, bottom pressure. ECCO Consortium Rep. 1.2, 54 pp., http://hdl.handle.net/1721.1/107613.
_ and Coauthors, 2017b: A twenty-year dynamical oceanic climatology: 1994-2013. Part 2: Velocities, property transports, meteorological variables, mixing coefficients. ECCO Consortium Rep. 1.3, 45 pp., http://hdl.handle.net/1721.1/109847.

Cabanes, C., T. Lee, and L. L. Fu, 2008: Mechanisms of interannual variations of the meridional overturning circulation of the North Atlantic Ocean. J. Phys. Oceanogr., 38, 467-480, https:// doi.org/10.1175/2007JPO3726.1.

Cai, W., P. H. Whetton, and D. J. Karoly, 2003: The response of the Antarctic Oscillation to increasing and stabilized atmospheric $\mathrm{CO}_{2}$. J. Climate, 16, 1525-1538, https://doi.org/10.1175/15200442-16.10.1525.

Cook, R. D., 1977: Detection of influential observation in linear regression. Technometrics, 19, 15-18, https://doi.org/10.1080/ 00401706.1977.10489493.

Cunningham, S. A., S. G. Alderson, B. A. King, and M. A. Brandon, 2003: Transport and variability of the Antarctic Circumpolar Current in the Drake Passage. J. Geophys. Res., 108, 8084, https://doi.org/10.1029/2001JC001147.

Dee, D. P., and Coauthors, 2011: The ERA-Interim reanalysis: Configuration and performance of the data assimilation system. Quart. J. Roy. Meteor. Soc., 137, 553-597, https:// doi.org/10.1002/qj.828.

Dong, S., J. Sprintall, and S. T. Gille, 2006: Location of the Antarctic polar front from AMSR-E satellite sea surface temperature measurements. J. Phys. Oceanogr., 36, 2075-2089, https://doi.org/10.1175/JPO2973.1.

Donohue, K. A., K. L. Tracey, D. R. Watts, M. P. Chidichimo, and T. K. Chereskin, 2016: Mean Antarctic Circumpolar Current 
transport measured in Drake Passage. Geophys. Res. Lett., $\mathbf{4 3}$ 11 760-11 767, https://doi.org/10.1002/2016GL070319.

Downes, S. M., A. S. Budnick, J. L. Sarmiento, and R. Farneti, 2011: Impacts of wind stress on the Antarctic Circumpolar Current fronts and associated subduction. Geophys. Res. Lett., 38, L11605, https://doi.org/10.1029/2011GL047668.

Durack, P. J., and S. E. Wijffels, 2010: Fifty-year trends in global ocean salinities and their relationship to broad-scale warming. J. Climate, 23, 4342-4362, https://doi.org/10.1175/2010JCLI3377.1.

Durbin, J., and G. S. Watson, 1950: Testing for serial correlation in least squares regression: I. Biometrika, 37, 409-428, https:// doi.org/10.2307/2332391.

Dytham, C., 2011: Choosing and Using Statistics: A Biologist's Guide. 3rd ed. Wiley-Blackwell, 320 pp.

Farneti, R., and Coauthors, 2015: An assessment of Antarctic Circumpolar Current and Southern Ocean meridional overturning circulation during 1958-2007 in a suite of interannual CORE-II simulations. Ocean Modell., 93, 84-120, https:// doi.org/10.1016/j.ocemod.2015.07.009.

Ffield, A., J. Toole, and D. Wilson, 1997: Seasonal circulation in the south Indian Ocean. Geophys. Res. Lett., 24, 2773-2776, https://doi.org/10.1029/97GL01253.

Forget, G., J. M. Campin, P. Heimbach, C. N. Hill, R. M. Ponte, and C. Wunsch, 2015: ECCO version 4: An integrated framework for non-linear inverse modeling and global ocean state estimation. Geosci. Model Dev., 8, 3071-3104, https://doi.org/ 10.5194/gmd-8-3071-2015.

$-,-,-\longrightarrow,-,-$ and,- 2016 : ECCO, version 4: Second release. ECCO Consortium, accessed 30 June 2017, http://hdl.handle.net/1721.1/102062.

Fukumori, I., O. Wang, I. Fenty, G. Forget, P. Heimbach, and R. M. Ponte, 2017: ECCO, version 4: Release 3. NASA-JPL, ftp:// ecco.jpl.nasa.gov/Version4/Release3/doc/v4r3_summary.pdf.

Ganachaud, A., and C. Wunsch, 2000: Improved estimates of global ocean circulation, heat transport, and mixing from hydrographic data. Nature, 408, 453-457, https://doi.org/10.1038/35044048.

,,-- J. Marotzke, and J. Toole, 2000: Meridional overturning and large scale circulation of the Indian Ocean. J. Geophys. Res., 105, 26117-26134, https://doi.org/10.1029/2000JC900122.

Gille, S. T., 2002: Warming of the Southern Ocean since the 1950s. Science, 295, 1275-1277, https://doi.org/10.1126/science.1065863.

_ 2008: Decadal-scale temperature trends in the Southern Hemisphere ocean. J. Climate, 21, 4749-4765, https://doi.org/ 10.1175/2008JCLI2131.1.

Hall, A., and M. Visbeck, 2002: Synchronous variability in the Southern Hemisphere atmosphere, sea ice, and ocean resulting from the annular mode. J. Climate, 15, 3043-3057, https:// doi.org/10.1175/1520-0442(2002)015<3043:SVITSH >2.0.CO;2.

Hogg, A. M., M. P. Meredith, D. P. Chambers, E. P. Abrahamsen, C. W. Hughes, and A. K. Morrison, 2015: Recent trends in the Southern Ocean eddy field. J. Geophys. Res. Oceans, 120, 257 267, https://doi.org/10.1002/2014JC010470.

Jackett, D. R., and T. J. McDougall, 1997: A neutral density variable for the world's oceans. J. Phys. Oceanogr., 27, 237-263, https://doi.org/10.1175/1520-0485(1997)027<0237:ANDVFT> 2.0.CO;2.

Lee, M. M., and A. Coward, 2003: Eddy mass transport for the Southern Ocean in an eddy-permitting global ocean model. Ocean Modell., 5, 249-266, https://doi.org/10.1016/S1463-5003(02) 00044-6.

Lilliefors, H. W., 1967: On the Kolmogorov-Smirnov test for normality with mean and variance unknown. J. Amer. Stat. Assoc., 62, 399-402, https://doi.org/10.1080/01621459.1967.10482916.
Losch, M., D. Menemenlis, J.-M. Campin, P. Heimbach, and C. Hill, 2010: On the formulation of sea-ice models. Part 1: Effects of different solver implementations and parameterizations. Ocean Modell., 33, 129-144, https://doi.org/10.1016/ j.ocemod.2009.12.008.

Lumpkin, R., and K. Speer, 2007: Global ocean meridional overturning. J. Phys. Oceanogr., 37, 2550-2562, https://doi.org/ 10.1175/JPO3130.1.

Lyman, J. M., and G. C. Johnson, 2014: Estimating global ocean heat content changes in the upper $1800 \mathrm{~m}$ since 1950 and the influence of climatology choice. J. Climate, 27, 1945-1957, https://doi.org/10.1175/JCLI-D-12-00752.1.

MacDonald, A. M., and C. Wunsch, 1996: An estimate of global ocean circulation and heat fluxes. Nature, 382, 436-439, https:// doi.org/10.1038/382436a0.

Marshall, J., and K. Speer, 2012: Closure of the meridional overturning circulation through Southern Ocean upwelling. Nat. Geosci., 5, 171-180, https://doi.org/10.1038/ngeo1391.

Mazloff, M. R., P. Heimbach, and C. Wunsch, 2010: An eddypermitting Southern Ocean state estimate. J. Phys. Oceanogr., 40, 880-899, https://doi.org/10.1175/2009JPO4236.1.

_- R. Ferrari, and T. Schneider, 2013: The force balance of the Southern Ocean meridional overturning circulation. J. Phys. Oceanogr., 43, 1193-1208, https://doi.org/10.1175/ JPO-D-12-069.1.

Meredith, M. P., and A. M. Hogg, 2006: Circumpolar response of Southern Ocean eddy activity to a change in the southern annular mode. Geophys. Res. Lett., 33, L16608, https://doi.org/ 10.1029/2006GL026499.

Mitsudera, H., and Coauthors, 2018: Low ocean-floor rises regulate subpolar sea surface temperature by forming baroclinic jets. Nat. Commun., 9, 1190, https://doi.org/10.1038/s41467-018-03526-z.

Moore, J. K., M. R. Abbott, G. Richman, and D. M. Nelson, 2000: The Southern Ocean at the Last Glacial Maximum: A strong sink for atmospheric carbon dioxide. Global Biogeochem. Cycles, 14, 455-475, https://doi.org/10.1029/1999GB900051.

Nyadjro, E. S., B. Subrahmanyam, and J. F. Shriver, 2011: Seasonal variability of salt transport during the Indian Ocean monsoons. J. Geophys. Res., 116, C08036, https://doi.org/10.1029/ 2011JC006993.

Piecuch, C. G., 2017: A note on practical evaluation of budgets in ECCO version 4 release 3. NASA-JPL Note, 34 pp., $\mathrm{ftp}: / /$ ecco.jpl.nasa.gov/Version4/Release3/doc/evaluating budgets_in_eccov4r3.pdf.

Rintoul, S. R., and A. C. Naveira Garabato, 2013: Dynamics of the Southern Ocean circulation. Ocean Circulation and Climate, G. Siedler et al., Eds., Elsevier, 471-492.

Roemmich, D., J. Gilson, R. Davis, P. Sutton, S. Wijffels, and S. Riser, 2007: Decadal spinup of the South Pacific subtropical gyre. J. Phys. Oceanogr., 37, 162-173, https://doi.org/10.1175/ JPO3004.1.

- - — P. Sutton, and N. Zilberman, 2016: Multidecadal change of the South Pacific gyre circulation. J. Phys. Oceanogr., 46, 1871-1883, https://doi.org/10.1175/JPO-D-15-0237.1.

Sen, P. K., 1968: Estimates of the regression coefficient based on Kendall's tau. J. Amer. Stat. Assoc., 63, 1379-1389, https:// doi.org/10.1080/01621459.1968.10480934.

Sen Gupta, A., and M. H. England, 2006: Coupled oceanatmosphere-ice response to variations in the southern annular mode. J. Climate, 19, 4457-4486, https://doi.org/10.1175/ JCLI3843.1.

Sloyan, B. M., and S. R. Rintoul, 2001: Circulation, renewal, and modification of the Antarctic Mode and Intermediate Water. 
J. Phys. Oceanogr., 31, 1005-1030, https://doi.org/10.1175/ 1520-0485(2001)031<1005:CRAMOA > 2.0.CO;2.

Sokolov, S., and S. R. Rintoul, 2009a: Circumpolar structure and distribution of the Antarctic Circumpolar Current fronts: 1. Mean circumpolar paths. J. Geophys. Res., 114, C11018, https://doi.org/10.1029/2008JC005108.

, and - 2009b: Circumpolar structure and distribution of the Antarctic Circumpolar Current fronts: 2. Variability and relationship to sea surface height. J. Geophys. Res., 114, C11018, https://doi.org/10.1029/2008JC005108.

Stammer, D., and Coauthors, 2003: Volume, heat, and freshwater transports of the global ocean circulation 1993-2000, estimated from a general circulation model constrained by World Ocean Circulation Experiment (WOCE) data. J. Geophys. Res., 108, 3007, https://doi.org/10.1029/ 2001JC001115.

Talley, L. D., 2003: Shallow, intermediate, and deep overturning components of the global heat budget. J. Phys. Oceanogr., 33, 530-560, https://doi.org/10.1175/1520-0485(2003)033<0530: SIADOC $>2.0 . \mathrm{CO} ; 2$.

, 2008: Freshwater transport estimates and the global overturning circulation: Shallow, deep and throughflow components. Prog. Oceanogr., 78, 257-303, https://doi.org/ 10.1016/j.pocean.2008.05.001.

_ 2013: Closure of the global overturning circulation through the Indian, Pacific, and Southern Oceans: Schematics and transports. Oceanography, 26 (1), 80-97, https://doi.org/10.5670/ oceanog.2013.07.

Thompson, A. F., 2010: Jet formation and evolution in baroclinic turbulence with simple topography. J. Phys. Oceanogr., 40, 257-278, https://doi.org/10.1175/2009JPO4218.1.
Thompson, D. W. J., and S. Solomon, 2002: Interpretation of recent Southern Hemisphere climate change. Science, 296, 895-899, https://doi.org/10.1126/science.1069270.

,-- P. J. Kushner, M. H. England, K. M. Grise, and D. J. Karoly, 2011: Signatures of the Antarctic ozone hole in Southern Hemisphere surface climate change. Nat. Geosci., 4, 741-749, https://doi.org/10.1038/ngeo1296.

Toggweiler, J. R., and B. L. Samuels, 1995: Effect of sea ice on the salinity of Antarctic Bottom Waters. J. Phys. Oceanogr., 25, 1980-1997, https://doi.org/10.1175/1520-0485(1995)025<1980: EOSIOT $>2.0 . \mathrm{CO} ; 2$.

Verdy, A., and M. Mazloff, 2017: A data assimilating model for estimating Southern Ocean biogeochemistry. J. Geophys. Res. Oceans, 122, 6968-6988, https://doi.org/10.1002/2016JC012650.

Vianna, M. L., and V. V. Menezes, 2011: Double-celled subtropical gyre in the South Atlantic Ocean: Means, trends, and interannual changes. J. Geophys. Res., 116, C03024, https://doi.org/ 10.1029/2010JC006574.

Wang, Z., T. Kuhlbrodt, and M. P. Meredith, 2011: On the response of the Antarctic Circumpolar Current transport to climate change in coupled climate models. J. Geophys. Res., 116, C08011, https://doi.org/10.1029/2010JC006757.

Watson, G. S., 1967: Linear least squares regression. Ann. Math. Stat., 38, 1679-1699, https://doi.org/10.1214/aoms/1177698603.

Wunsch, C., and P. Heimbach, 2009: The global zonally integrated ocean circulation, 1992-2006: Seasonal and decadal variability. J. Phys. Oceanogr., 39, 351-368, https://doi.org/10.1175/ 2008JPO4012.1.

Zheng, Y., and B. S. Giese, 2009: Ocean heat transport in Simple Ocean Data Assimilation: Structure and mechanisms. J. Geophys. Res., 114, C11009, https://doi.org/10.1029/2008JC005190. 